\title{
Molecular and Functional Roles of MicroRNAs in the Progression of Hepatocellular Carcinoma-A Review
}

\author{
Kyoko Oura $₫$, Asahiro Morishita *® and Tsutomu Masaki \\ Department of Gastroenterology and Neurology, Kagawa University, 1750-1 Ikenobe, Miki 761-0793, Japan; \\ kyoko_oura@med.kagawa-u.ac.jp (K.O.); tmasaki@med.kagawa-u.ac.jp (T.M.) \\ * Correspondence: asahiro@med.kagawa-u.ac.jp; Tel.: +81-87-891-2156
}

Received: 4 October 2020; Accepted: 5 November 2020; Published: 7 November 2020

\begin{abstract}
Liver cancer is the fourth leading cause of cancer deaths globally, of which hepatocellular carcinoma (HCC) is the major subtype. Viral hepatitis B and C infections, alcohol abuse, and metabolic disorders are multiple risk factors for liver cirrhosis and HCC development. Although great therapeutic advances have been made in recent decades, the prognosis for HCC patients remains poor due to late diagnosis, chemotherapy failure, and frequent recurrence. MicroRNAs (miRNAs) are endogenous, non-coding RNAs that regulate various molecular biological phenomena by suppressing the translation of target messenger RNAs (mRNAs). miRNAs, which often become dysregulated in malignancy, control cell proliferation, migration, invasion, and development in HCC by promoting or suppressing tumors. Exploring the detailed mechanisms underlying miRNA-mediated HCC development and progression can likely improve the outcomes of patients with HCC. This review summarizes the molecular and functional roles of miRNAs in the pathogenesis of HCC. Further, it elucidates the utility of miRNAs as novel biomarkers and therapeutic targets.
\end{abstract}

Keywords: microRNA; non-coding RNA; hepatocellular carcinoma; biomarker; therapeutic target; therapy resistance; $\mathrm{HBV} ; \mathrm{HCV}$; fibrosis; inflammation

\section{Introduction}

\subsection{Hepatocellular Carcinoma}

Liver cancer is the fourth leading cause of cancer deaths globally, after lung, colorectal, and stomach cancers [1]. Hepatocellular carcinoma (HCC) is the major subtype, accounting for more than $80 \%$ of primary liver cancers [2]. Multiple risk factors are associated with the occurrence of HCC, including chronic viral hepatitis B (HBV) or C (HCV) infections, which account for $80 \%$ of HCC cases worldwide [3]. Although alcoholic liver disease (ALD) is a common cause of HCC in the USA and Europe, the numbers of patients with nonalcoholic fatty liver disease (NAFLD) have recently increased in most developed countries, and NAFLD is now frequently listed as a cause of HCC $[4,5]$. Great therapeutic advances have been made in recent decades; however, the prognosis for HCC patients remains poor with a 5-year survival rate of $15-38 \%$ in the USA and Asia, attributed to late diagnosis, chemotherapy failure, and frequent recurrence [6-8]. Therefore, exploring the detailed mechanisms underlying HCC development and progression is an effective means of improving the outcomes of HCC patients.

\subsection{MicroRNAs}

Non-coding RNAs lack sequences that encode proteins or peptides; these are classified into small non-coding RNAs of about 20-30 bases and long non-coding RNAs of several hundred kbp. Small non-coding RNAs include microRNAs (miRNAs), small interfering RNA (siRNA), 
and PIWI-interacting RNA (piRNA). Among these, miRNAs are endogenous, small non-coding RNAs (approximately 19-25 nucleotides in length) that regulate gene expression through degradation of messenger RNAs (mRNAs) or inhibition of translation by binding to the $3^{\prime}$ untranslated region (UTR) of target mRNAs. miRNAs control cell proliferation, migration, invasion, and development in HCC by acting as tumor promoters or suppressors $[9,10]$. Each miRNA is thought to be capable of post-transcriptionally repressing hundreds of target genes; they are thus strong regulators of gene expression.

The biogenesis of miRNAs, and the mechanisms whereby they regulate translation by binding their target mRNAs, are illustrated in Figure 1. Primary miRNAs (pri-miRNA) are transcribed from DNA in the nucleus by RNA polymerase II and are approximately 3-4 kilobases long with a hairpin structure. They are processed by a nuclear RNase III enzyme (Drosha) and its partner protein DiGeorge syndrome critical region 8 (DGCR8), resulting in intermediate pre-miRNAs of approximately 70 nucleotides in length. Then, exportin-5 and its partner Ran-GTP bind to the pre-miRNA, and the complex is exported from the nucleus to the cytoplasm. The hairpin pre-miRNA is cleaved by ribonuclease III (Dicer) and the transactivation response element RNA-binding protein (TRBP), and is processed into a double-stranded mature miRNA of approximately 22 nucleotides in length. The double-stranded miRNA is then unwound, and one strand forms the RNA-induced silencing complex (RISC) with argonaute (Ago). The miRNA separates into mature, single-stranded miRNA, which is selected depending upon its stability, while less stable miRNA strands are degraded. Complementary base pairing between the seed region of the mature miRNA and the target mRNA results in the degradation of the mRNAs and translational repression [11,12].

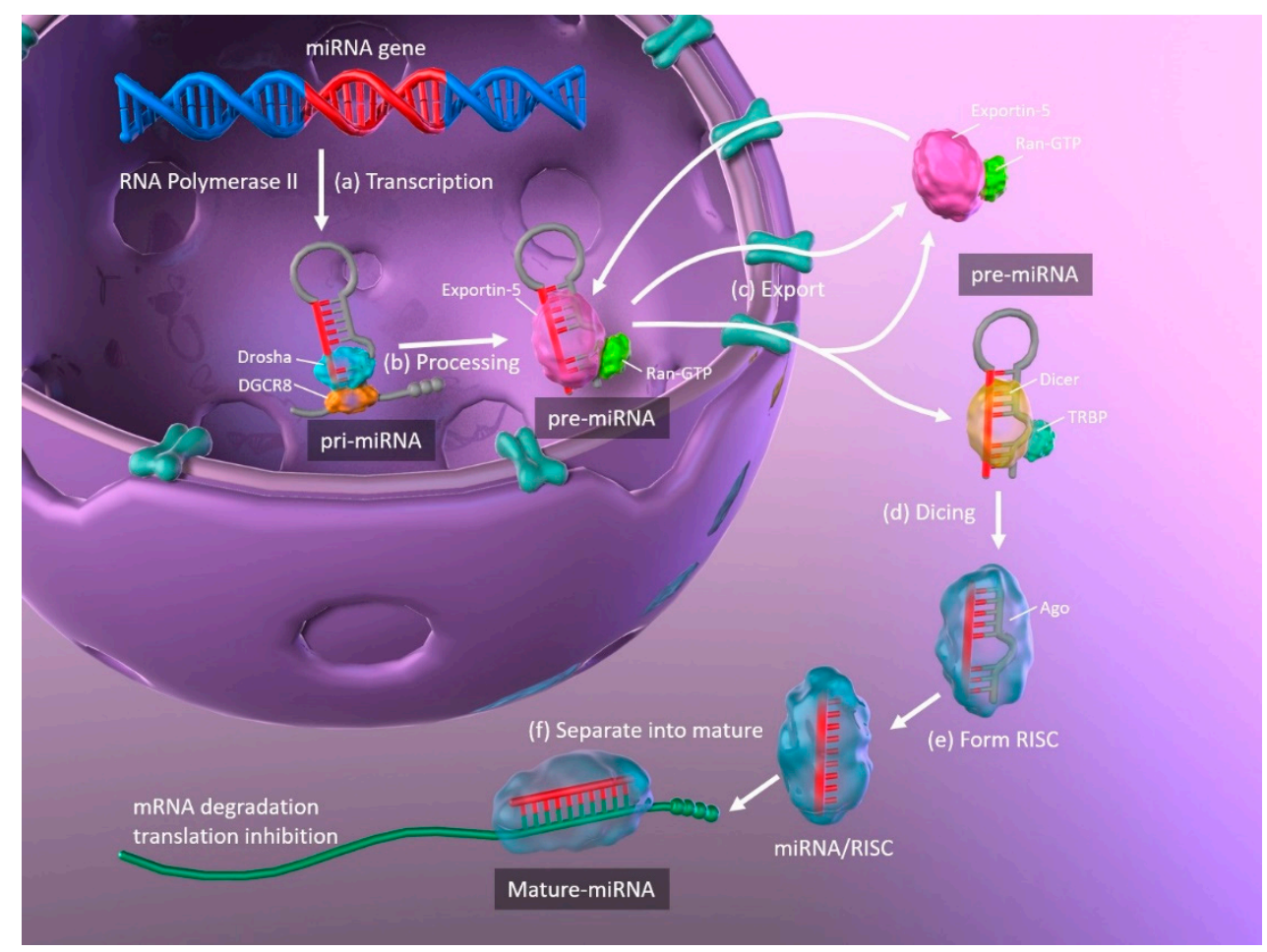

Figure 1. Schematic representation of miRNA biogenesis. (a) Synthesis of pri-miRNA transcripts from DNA. (b) pri-miRNA is processed by Drosha and DGCR8, resulting in a hairpin intermediate pre-miRNA. (c) Exportin-5 and Ran-GTP bind to pre-miRNA, and the complex is exported from the nucleus to the cytoplasm. (d) The hairpin pre-miRNA is cleaved by Dicer and TRBP. (e) The double-stranded miRNA is unwound and forms RISC with Ago. (f) The miRNA separates into mature, single-stranded miRNA. miRNA: microRNA; pri-miRNA: primary microRNA; DGCR8: DiGeorge syndrome critical region 8; TRBP: transactivation response element RNA-binding protein; RISC: RNA-induced silencing complex; Ago: argonaute. 
miRNAs regulate approximately $30 \%$ of human genes via the pathway described above, many of which regulate various carcinogenic molecules and pathways or are located on unstable loci $[13,14]$. miRNAs have been shown to be dysregulated in most cancers. Oncogenic miRNAs (OncomiRs) and tumor-suppressive miRNAs are associated with carcinogenesis and malignant transformation contributing to or repressing the cancer phenotype. Overexpression of oncomiRs have been observed in various cancers [15]. Dysregulation of miRNAs in cancer has frequently been described in gastrointestinal [16,17], urological [18,19], gynecological [20], and lung cancers [21]. Increasing numbers of recent reports have described the utility of miRNAs as biomarkers or therapeutic targets in HCC [22,23]. In this review, we summarize the molecular and functional roles of miRNAs in the pathogenesis of HCC. Further, we describe the potential for using miRNAs as biomarkers and novel therapeutic targets in HCC, based on recent reports.

\section{The Role of miRNAs in Liver Regeneration}

The liver has an exceptionally high regeneration capacity compared to other human organs. Therefore, in cases of liver damage, hepatocyte loss after hepatectomy, or secondary liver dysfunction, hepatocytes in the remaining liver tissue expand and proliferate to restore liver volume and function. Liver regeneration is a complex and regulated phenomenon in which multiple cell types that make up the liver interact via various signaling factors. Although the mechanisms of liver regeneration in the injured liver are clinically important, much remains unknown. Here, we summarized recent findings on the roles and importance of cell proliferation and apoptosis in liver regeneration.

\subsection{Cell Proliferation in Hepatocytes}

During regeneration and repair following liver injury, hepatocytes undergo division in three stages-initiation, growth, and termination. During initiation, hepatocytes are stimulated by cytokines such as interleukin-6 (IL-6) and tumor necrosis factor- $\alpha$ (TNF- $\alpha$ ) shift from the G0 cell-cycle phase to the G1 phase. In the subsequent growth phase, G1-phase hepatocytes proliferate by promoting the cell cycle in a cyclin-dependent manner, under stimulation by the hepatocyte growth factor (HGF). When liver volume and function return to normal after the growth phase, hepatocytes are stimulated by TGF- $\beta$ and actin to terminate proliferation and return to the G0 phase [24]. Liver regeneration is precisely controlled by various molecular mechanisms. In particular, miRNAs have recently been documented to play key roles in the processes of cell proliferation [25-29].

The role of miRNAs and general miRNA changes during the initiation phase has long been known. One study revealed that approximately $40 \%$ of miRNAs had increased $3 \mathrm{~h}$ after partial hepatectomy, including those that targeted miRNA synthesis (Drosha, DGCR8, Dicer, and TRBP), whereas approximately $70 \%$ had declined at $24 \mathrm{~h}$ [25]. A transient increase in miRNAs acts as an initiation signal for cell proliferation, thus providing negative feedback that causes general miRNA changes after $24 \mathrm{~h}$ and promotes cell proliferation.

During the growth phase, the abundance of several miRNAs also declines; the levels of most miRNAs were lower within $3 \mathrm{~d}$ after partial hepatectomy, and gene expression related to cell cycle and proliferation were accordingly higher [26]. In contrast, several studies have reported increases in miRNA abundance during the growth phase, in which increased miR-21 plays an important role. miR-21 has been shown in vitro to control the transition from G1 to the $S$ phase in primary hepatocyte proliferation and accelerate rapid S-phase entry by targeting a negative cell proliferation regulator, phosphatase, and tensin homolog deleted on the chromosome (PTEN) [27]. Further, an in vivo study demonstrated that miR-21 is a critical regulator of liver regeneration and its upregulation contributed to hepatocyte proliferation by targeting PTEN [28]. It was recently shown that the loss of Dicer1 inhibited liver regeneration by downregulating Dicer1-dependent miRNAs, including miR-21. Further, the introduction of miR-21 restored liver regeneration by inhibiting PTEN and Ras homolog family member B (RhoB). RhoB facilitates activation of the phosphoinositide 3-kinase (PI3K)/AKT/mammalian target of rapamycin (mTOR) axis [29]. 
Many miRNAs suppress the proliferation of hepatocytes after the initiation phase and induce liver regeneration until the termination phase is reached. miR-23b, which promotes cell proliferation by small mother against decapentaplegic targeting 3 (SMAD3) and inhibiting the TGF- $\beta$ pathway, was highly expressed up to $24 \mathrm{~h}$ after partial hepatectomy; however, its expression subsequently declined consistently from 3 to 7 days [30]. In contrast, miR-34a, which acts as a growth inhibitor, was consistently overexpressed up to $24 \mathrm{~h}$ after partial hepatectomy [31]. Blocking or stimulating miRNA pathways during liver regeneration may provide novel therapeutic strategies for managing liver regeneration [32].

\subsection{Apoptosis in Hepatocytes}

Apoptosis refers to highly regulated cell death; it occurs not only in morphogenesis during development, but also serves to control cell numbers and to remove damaged cells in liver steatosis, inflammation, and fibrosis. It, therefore, plays an important role in hepatocarcinogenesis. Several miRNAs regulate programmed cell death via intrinsic (BCL2 and MCL1) and extrinsic (TNF-related apoptosis-inducing ligand; TRAIL and Fas) regulatory pathways and the p53-mediated and endoplasmic reticulum stress-induced apoptosis pathway [33]. The following section describes the primary roles of miRNAs in regulating the key molecules involved in the hepatocyte apoptotic pathway. miR-15b and miR-16 are TNF-related apoptosis regulators via the antiapoptotic protein BCL2. In severe liver inflammation, miR-15b and miR-16 were upregulated in liver tissues and regulated BCL2 at the protein level; moreover, inhibition of these miRNAs reduced TNF-mediated apoptosis in the liver [34]. Recent evidence indicates that miR-15b can inhibit cell proliferation and downregulate BCL2 mRNA and protein expression in hepatocytes [35].

Abnormal expression of miR-125b is common in various cancers; miR-125b plays dual roles to induce or inhibit apoptosis, depending on the cellular state. Similarly, miR-125b downregulation is frequently observed in HCC development; low expression of miR-125b in HCC tissues correlates with a higher rate of apoptosis [36]. miR-125b is thought to promote apoptosis by directly targeting BCL family members such as MCL1, BCLw, and IL-6R [36]. Therefore, miR125b downregulation may promote malignant transformation and tumor development.

miR-221 and its paralog miRNA-222 have been shown in several studies to aggravate hepatocarcinogenesis by targeting apoptosis-related factors, such as p53, p53 upregulated modulator of apoptosis (PUMA), NF-kB, and signal transducer and activator of transcription 3 (STAT3) [37,38]. During hepatocellular carcinogenesis in vitro and in vivo, miR-221/222 induced TRAIL resistance by regulating tumor suppressors such as PTEN and tissue inhibitor of metalloproteinase 3 (TIMP3), and enhanced cell migration by activating the AKT pathway and metallopeptidase activity [39]. In mice, overexpression of miR-221 led to antiapoptotic effects and delayed liver failure progression by regulating the expression of PUMA in the liver [40].

\section{The Role of miRNAs in Liver Diseases Associated with HCC}

\subsection{Hepatic Lipid Metabolism}

The liver controls the metabolism of fatty acids and triglycerides, and plays an important role in regulating whole-body lipid homeostasis. Excessive accumulation of lipids in the liver is characteristic of several liver diseases, such as ALD and NAFLD, which includes nonalcoholic steatohepatitis (NASH). There is some evidence that miR-122 and miR-34a are important molecules in maintaining metabolic homeostasis in the liver.

miR-122 is highly expressed in the liver specifically, accounting for $70 \%$ of its total miRNA content. More than 66,000 copies of miR-122 per hepatocyte are present in the liver, and miR-122 is generally most highly expressed in any liver tissue, including normal and fatty livers [41]. In the liver, miR-122 regulates the expression of various genes related to lipid metabolism [42]. In healthy mice, miR-122 inhibition reduced the expression of hepatic lipogenesis genes, which encode two rate-limiting enzymes, 
fatty acid synthase (FASN) and acetyl-CoA carboxylase 1 (ACC1). However, miR-122 inhibition in obese mice reduced hepatic lipogenesis and protected against liver steatosis [41]. Furthermore, miR-122 overexpression reduced the expression of insulin-like growth factor (IGF)-1R. Hepatocyte nuclear factor (HNF)- $4 \alpha$ is a key regulator of miR-122 activity and of various targets associated with gluconeogenesis and lipogenesis [43]. miR-122 expression was lower in liver samples [44,45] but higher in serum [46-48] from patients with NAFLD compared with healthy controls. These results concurred with those of an earlier study, in which miR-122 inhibition caused a significant decrease in serum cholesterol levels and improved hepatic steatosis in high-fat diet mice. This was associated with the activation of adenosine $5^{\prime}$-monophosphate-activated protein kinase (AMPK), increased hepatic fatty acid oxidation, and decreased hepatic lipid synthesis rates [49].

miR-34a targets hepatic sirtuin 1 (SIRT1), which modulates energy metabolism by activating peroxisome proliferator-activated receptor (PPAR) $\alpha$ and liver $\mathrm{X}$ receptor (LXR) [44,50]. SIRT1 is also downregulated in NAFLD, and miR-34a inhibition restores SIRT1 expression, which leads to the activation of AMPK [51]. A recent study found that induction of miR-34a, which also regulates caspase-2 levels, contributed to liver steatosis in both humans and mice [52]. Similarly, miR-33, miR-103, miR-104, and miR-307 reportedly modulated lipid and cholesterol regulatory genes [53]. miR-33a and miR-33b, pivotal regulators of lipid metabolism in the liver, play important roles in lipid metabolism with respect to sterol regulatory element-binding protein (SREBP) genes.

\subsection{Hepatic Inflammation}

Liver inflammatory disease is caused by an immune response resulting from various factors, including bacterial and viral infections, alcohol abuse, metabolism disorders, drugs, and diet. Hepatic inflammation and the immune response cause the production of inflammatory mediators, including TNF, IL-1, and IL-6 in macrophages and endothelial cells, which play key roles in inflammatory regulation. In particular, miRNAs such as miR-122, miR-132, and miR-155 have important functions in innate and adaptive immunity associated with liver inflammation. As previously mentioned, miR-122 not only regulates cholesterol and lipid metabolism but also has important roles in hepatic inflammation. miR-122-deficient mice displayed hepatic inflammation and fibrosis, suggesting that miR-122 plays an anti-inflammatory role. This pathology is associated with activation of the carcinogenic pathway, and with hepatic infiltration by inflammatory cells to release protumorigenic mediators such as IL-6 and TNF. Further, miR-122 strongly inhibits tumor formation [54,55]. miR-132 is a well-known mediator in chronic liver disease and has been shown to enhance interaction between adipocytes and inflammatory cells during malnutrition through the inhibition of SIRT1 and deacetylation of p65 [56]. Suggesting the intracellular role in liver inflammation, long-term alcohol administration in mice induced miR-132 throughout the liver and in isolated hepatocytes and Kupffer cells [57]. miR-155 is also expressed in Kupffer cells after alcohol administration, and TNF-induced miR-155 potentially worsens liver inflammation. Elevated serum miR-155 has been found following liver inflammation in individuals with excessive alcohol intake and mice with alcoholic liver injury $[58,59]$.

\subsection{Hepatic Fibrosis}

Hepatic fibrosis progresses with the exposition of the extracellular matrix due to alcohol abuse, cholestasis, and parasite and hepatitis virus infections [60]. Activated hepatic stellate cells (HSCs) in the liver are known to be major effectors associated with hepatic fibrosis. Activation of HSCs via multiple signaling pathways causes severe inflammation and miRNAs are known to modulate various growth-factor receptor signals [61]. miR-21 can mediate activation of human HSCs during hepatic fibrosis via the PTEN/AKT pathway [62]. Patients with chronic hepatitis including Schistosoma japonicum-related hepatic fibrosis exhibit downregulation of SMAD7, a negative regulator of transforming growth factor (TGF)- $\beta$ signaling, which modulates fibrosis and TGF- $\beta$, in turn, induces miR-21 [63,64]. Recently, it was reported that miR-96, like miR-21, 
promotes schistosomiasis-related hepatic fibrosis by activating the SMAD signaling pathway, and increases collagen expression by targeting SMAD7 [65].

miR-221 has been shown to play a key role in liver fibrosis; many reports have demonstrated that it is upregulated in hepatic fibrosis [66], and that it is an effective non-invasive biomarker for evaluation of HCV- or NASH-induced hepatic fibrosis [67-69]. In vivo deletion of the miR-221/222 cluster in the liver suppressed TIMP3, a secreted protein that binds to the extracellular matrix and blocks activation of several cell membrane metalloproteases, including a disintegrin and metalloproteinase 17 (ADAM17) and TNF- $\alpha$ converting enzyme; suppression of TIMP3 by deleting the miR-221/222 cluster inhibited hepatic fibrosis $[70,71]$.

Among the other miRNAs associated with hepatic fibrosis, miR-181b promotes hepatic fibrosis via the TGF- $\beta$ or NF- $k$ B pathways, whereas miR-29b, miR-101, and miR-214-3p suppress hepatic fibrosis by suppressing collagen production in the extracellular matrix or by inhibiting the TGF- $\beta$ pathway [72]. miR-29a was downregulated in the serum of hepatic fibrosis patients [73]. miR-29a overexpression obstructed signaling of toll-like receptor 2(TLR2) and TLR4, key mediators of hepatic fibrosis in Kupffer cells and HSCs, in liver tissues of cholestatic mice [74].

Various miRNA signatures in liver diseases have been recently identified (Table 1).

Table 1. microRNAs (miRNAs) associated liver diseases.

\begin{tabular}{cccc}
\hline Liver Disease & miRNA & Function & Reference \\
\hline \multirow{2}{*}{ HBV infection } & miR-122, miR-99 family & Promote HBV replication & {$[75,76]$} \\
& miR-199-3p, miR-201 & Suppress HBV replication & {$[77]$} \\
\hline \multirow{2}{*}{ HCV infection } & miR-141 & Promote HCV replication & {$[78,79]$} \\
& let-7 family, miR-21 & Suppress liver fibrosis & {$[63,80]$} \\
& miR-16, miR-146a, & Biomarker for liver fibrosis & {$[81]$} \\
\hline ALD & let-7 family, miR-19b & Suppress liver fibrosis & {$[82,83]$} \\
\hline NAFLD/NASH & miR-155 & Promote carcinogenesis & {$[84-86]$} \\
\hline
\end{tabular}

\subsection{Hepatitis B Virus}

HBV infection causes a spectrum of liver disease depending on the balance between virus replication ability and host immune status; that is, it progresses from the asymptomatic carrier state, acute hepatitis, chronic hepatitis, and eventually to liver cirrhosis and/or HCC. The host immune response to eliminate HBV elicits cytotoxic T-cell responses with the production of inflammatory cytokines, including free radicals, interferon, and TNF, resulting in liver injury. Integration of HBV into the host hepatocyte genome is important for hepatocarcinogenesis, which triggers apoptosis, regeneration, early senescence, and genomic instability [87].

miRNAs directly target HBV transcripts. miR-199-3p binds directly to the S protein-coding region and miR-201 binds to the pre-S region, resulting in suppression of HBV replication [77]. Several miRNAs target HBV transcripts and regulate HBV-associated liver carcinogenesis by suppressing the wingless-related integration site $(\mathrm{WNT}) / \beta$-catenin, Janus kinase (JAK)/STAT, and PI3K/mitogen-activated protein kinase (MAPK) pathways [88].

miR-122 targets the mRNA coding for HBV polymerase and the $3^{\prime}$ UTR of the mRNA for the core protein [89]. However, it is well known that miR-122 also targets certain proteins; the downregulation of WNT1 by miR-122 leads to the downregulation of $\beta$-catenin [90]. The reduction in miR-122 expression in HBV can upregulate cyclin G1, which attenuates p53 activity, thereby increasing HBV replication [75]. This key miRNA can also downregulate the suppressor of cytokine signaling 3 (SOCS3), which negatively regulates JAK/STAT signaling. Therefore, inhibition of miR-122 induced by chronic HBV infection upregulates SOCS3 and leads to inactivation of interferon, thus promoting viral persistence and hepatocarcinogenesis [91]. 
miR-155, which controls the generation of class-switch B cells and c-myc-IgH translocation, acts as an immune regulator, controlling cell proliferation, and maintaining homeostasis [92]. A recent study found that increased miR-155 expression levels were positively correlated with measured values of liver enzymes and hepatitis Be (HBe) antigens in the serum of patients with acute HBV infection [93]. HBe antigens increase miR-155 expression in inflammatory cells via the PI3K and NF- $\mathrm{KB}$ signaling pathways; this promotes the production of HBe antigen-induced inflammatory cytokines by suppression of BCL6, SH2-containing inositol phosphatase 1 (SHIP1), and SOCS [93].

A recent study revealed that miR-99 family members were highly expressed in HBV-infected liver tissues and that miR-99 levels corresponded with HBV DNA loads in the serum of patients with HBV infection [76]. Transfection of the miR-99 family (miR-99a, miR-99b, and miR-100) promoted HBV replication and antigen expression in HCC cells. Overexpression of the miR-99 family suppressed activation of the IGF-1R/AKT/mTOR pathway and promoted post-transcriptional HBV replication via autophagy through mTOR/Unc-51 like autophagy activating kinase 1 (ULK1) signaling [76].

\subsection{Hepatitis C Virus}

$\mathrm{HCV}$, a hepatotropic RNA virus belonging to the Flaviviridae family, is a primary contributor to liver cirrhosis and HCC with persistent chronic hepatitis. Some miRNAs associated with the host immune response to HCV infection not only regulate the target genes involved in replication, but also directly target the HCV genome [78]. Many host factors, such as poly(rC)-binding protein (PCBP) 2 and miR-122, bind to the $5^{\prime}$ UTR of the viral genome, thus controlling the replication of HCV. Like other miRNAs, miR-122 normally forms a complex with Ago2; it then binds to the 3' UTR of the target mRNA and suppresses translation or promotes degradation of mRNA, thereby negatively regulating gene expression. In contrast, $\mathrm{HCV}$ has two miR-122 binding sites at its genomic RNA $5^{\prime}$ UTR; binding of the miR-122/Ago2 complex to these sites stabilizes the viral RNA and inhibits its degradation $[94,95]$. HCV infection disrupts miRNA regulation of multiple pathways including the immune system, cell proliferation, signal transduction, and lipid metabolism [96].

Several miRNAs are required for HCV replication. miR-141 significantly promotes $\mathrm{HCV}$ replication by downregulating Rho GTPase activating protein (DLC) 1 [79], and miR-491 helps HCV entry through the PI3 kinase/AKT pathway [78]. Further, HCV infection causes changes in the expression of other miRNAs including miR-130a/b, miR-200, miR-34a, miR-23b, miR-24, miR-146a, miR-381, miR-25, miR-200a, and miR-371-5p. The miRNAs regulate the gene expressions associated with PPAR $\gamma$, STAT3, interferon regulatory factor 1 (IRF1), IGF-1R, fibronectin 1 (FN1), stearoyl-CoA desaturase (SCD), and cAMP-responsive element-binding protein 1(CREB1) [78,97].

Differential miRNA expression has been reported in livers with progressed fibrosis and is involved in HSC activation [98]. Several miRNAs are reportedly useful biomarkers for evaluating the progression of hepatic fibrosis in chronic hepatitis or cirrhosis due to HCV infection. Expression levels of the let-7 family (let-7a-5p, let-7c-5p, and let-7d-5p) were inversely correlated with the degree of hepatic fibrosis due to HCV infection, and low expression of the let-7 family influenced hepatic fibrosis through activation of the TGF- $\beta$ pathway in HSCs [80]. miR-21 was also a TGF- $\beta$-mediated fibrosis modulator in HCV-infected patients with downregulated SMAD7, which suppressed TGF- $\beta$ signaling [63]. A recent cohort study demonstrated that miR-16, miR-146a, miR-221, and miR-222 were effective biomarkers for predicting the progression of hepatic fibrosis due to HCV. miR-221 and miR-222 are particularly important biomarkers with high sensitivity and specificity in the advanced stage of hepatic fibrosis due to persistent HCV infection [81].

\subsection{Alcoholic Liver Disease}

ALD, including steatosis, alcoholic hepatitis, and liver cirrhosis, is caused by persistent degeneration and necrosis of hepatocytes due to alcohol abuse. The toxicity of alcohol increases the production of reactive oxygen species, resulting in hepatocyte damage and hepatitis due to free radicals and oxidative stress. Since ALD may eventually cause HCC, it is an important condition in the study of 
hepatocarcinogenesis. ALD often progresses through immune mechanisms including the TLR4-NF- $\mathrm{KB}$ pathway. Moreover, TLR4 triggers the activation of MAPK or TIR-domain-containing adapter-inducing interferon- $\beta$ (TRIF) [99]. Chronic overdose of alcohol intake reduces miR-155 expression and inhibits the expression of multiple TLR4-NF-KB regulators including SHIP1 and SOCS1 [84]. Moreover, several miRNAs (miR-27a, miR-30a, miR-103, miR-107, miR-122, miR-182, and miR-192) are known to regulate inflammatory cytokines associated with ALD [84].

A recent study suggested that let-7 family members, including let-7a and let-7b, were downregulated in mouse livers following ethanol consumption. These miRNAs directly targeted Lin28B and high-mobility group AT-hook 2 (HMGA2). Furthermore, low expression of Lin28B induced overexpression of the let-7 family and suppressed HSC activity and hepatic fibrosis in mice with ALD [82]. In an in vivo study, miR-19b levels were reduced in liver tissues from rat models of alcoholic-induced liver injury, concomitant with a significant increase in pri-miR-17-92 expression and enhancement of profibrotic markers [83]. miR-182 was one of the most overexpressed miRNAs in patients with alcoholic hepatitis compared with patients with other chronic liver conditions; its expression was correlated with the degree of disease progression and short-term mortality [100].

\subsection{Nonalcoholic Fatty Liver Disease}

NAFLD results from fat accumulation in the liver, mainly due to obesity and lifestyle-related diseases in the absence of alcohol abuse, hepatitis viral infection, or other specific causes. It includes the pathology of NASH, which refers to steatosis with inflammation caused by triglyceride accumulation, and can progress to fibrosis, cirrhosis, and hepatocarcinogenesis over a long period. The pathogenesis of NASH, which remains to be fully elucidated, is associated with insulin resistance, dysfunction of adipokine secretion, increased fatty acid $\beta$-oxidation in mitochondria, accumulation of misfolded proteins in the endoplasmic reticulum stress, excessive fatty acid consumption, iron overload, production of proinflammatory cytokines in macrophages, small intestinal bacterial overgrowth, and genetic factors [84].

Recent studies indicated that the livers of patients with NAFLD exhibited different miRNA profiles compared to healthy controls. NAFLD liver tissues have upregulated expression of miR-31, miR-33a, miR-34a, miR-144, miR-146b, miR-150, miR-182, miR-183, miR-200a, miR-224, and miR-301a, and downregulated miR-17, miR-122, miR-296, miR-373, miR-375, and miR-378c expression [84,101,102]. In particular, miR-34a and miR-122 play pivotal roles associated with the progression of NAFLD, including NASH and hepatocarcinogenesis, as mentioned in Section 3.1 [42,43,49,51]. miR-155 regulates the function of immune cells and is involved in lipid metabolism [103] and ALD [84]. miR-155 activity is reduced by adipogenic transcription factors CCAAT/enhancer-binding protein (C/EBP)- $\alpha$, C/EBP- $\beta$, PPAR- $\gamma$, and LXR $\alpha$ in NAFLD patients; further, miR-155 is implicated in carcinogenesis in NAFLD [84-86].

\section{Dysregulation of miRNAs in HCC}

Each miRNA targets multiple mRNAs and regulates the expression of multiple genes in a complex manner; these dysregulations are observed in various cancer types [16-21,104]. While some miRNAs are downregulated in HCC, acting as tumor suppressors, upregulated miRNAs also occur in HCC, functioning as oncomiRs. Regions encoding miRNAs involved in dysfunction can harbor genetic alterations such as mutations, amplifications, deletions, or fusions. Transcription of some miRNAs is suppressed by carcinogenesis transcription factors such as Myc, while others are epigenetically regulated by DNA methylation and histone modifications. Additionally, suppression of miRNA processing machinery genes, including Drosha, DGCR8, Dicer, TRBP, and Ago2 has been shown to reduce mature miRNA synthesis, leading to hepatocarcinogenesis and HCC development [104].

In HCC, miRNA dysregulation is involved in all clinical stages, and is evident even in early stages; therefore, miRNA profiles may potentially be used to discriminate HCC patients from healthy controls and those with other liver diseases [105]. Various HCC-specific miRNA signatures have been 
recently identified (Tables 2 and 3). In a previous study, we reported that miRNA profiles differed between hepatocytes and HCC cell lines [106], suggesting that miRNA profiles have significant value as biomarkers $[107,108]$. Insights into the roles of miRNAs in HCC development and progression have made miRNAs attractive biomarkers and therapeutic targets for HCC.

Table 2. Recently reported upregulated miRNAs acting as oncomiRs in hepatocellular carcinoma (HCC).

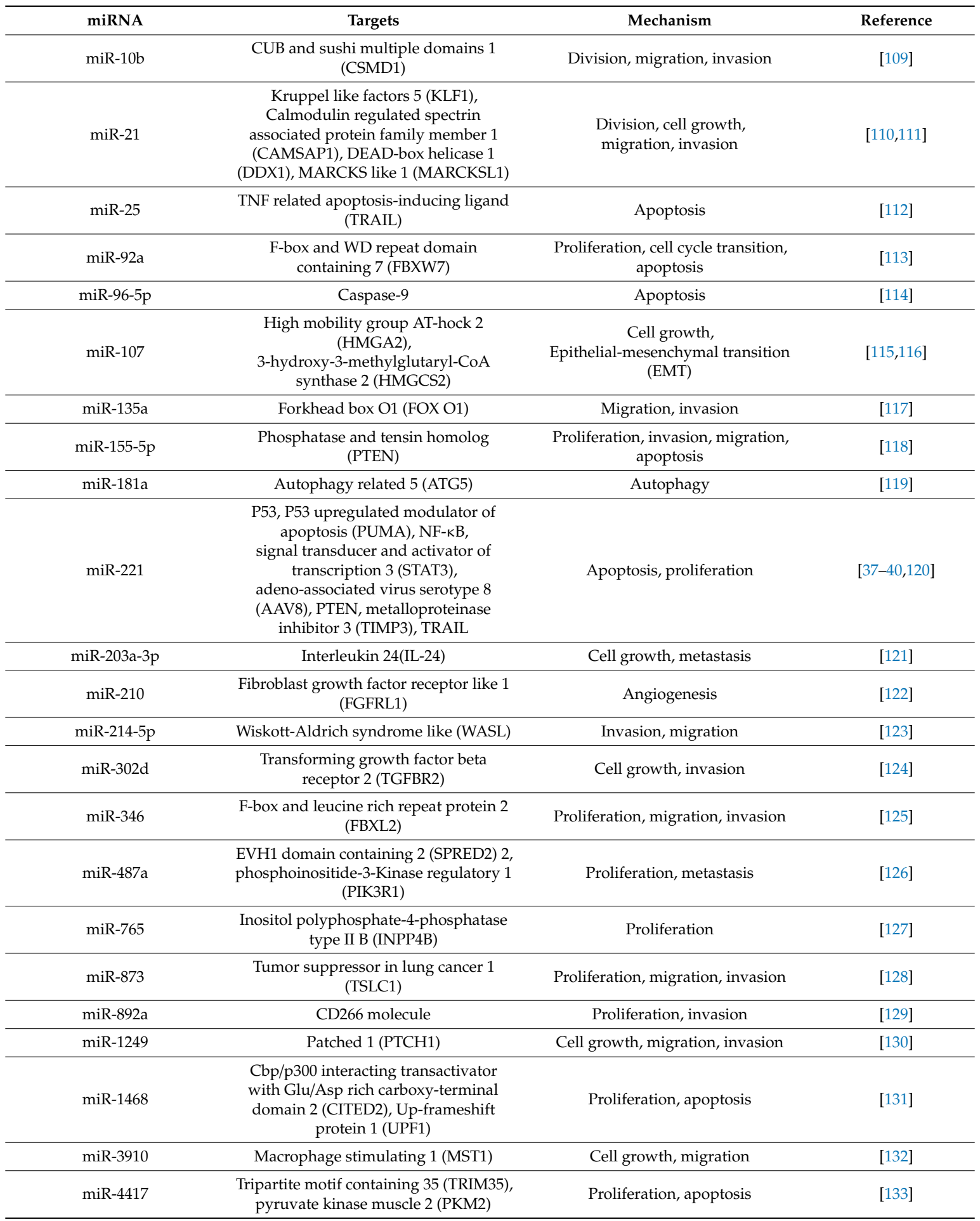


Table 3. Recently reported downregulated miRNAs acting as tumor suppressors in HCC.

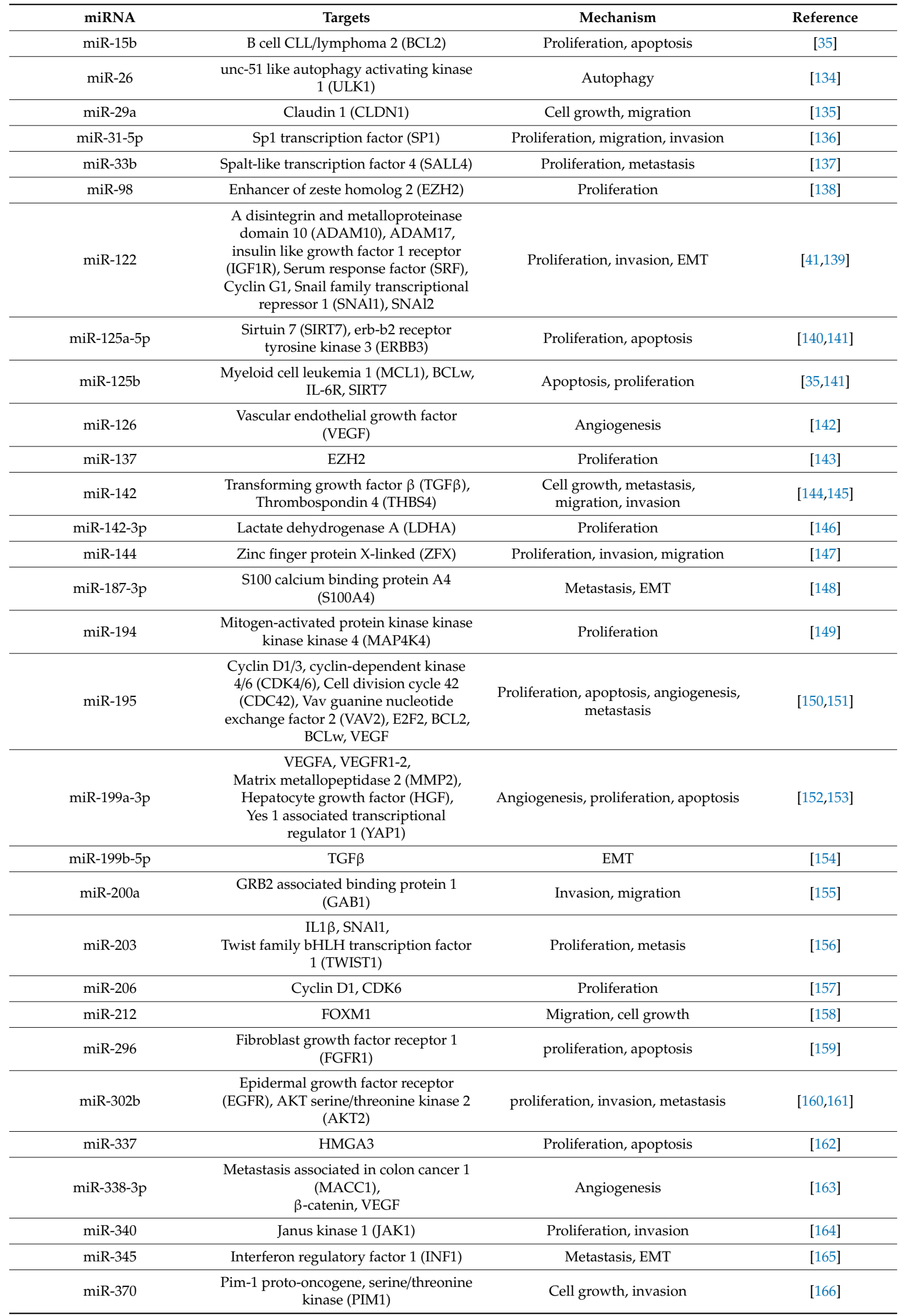


Table 3. Cont.

\begin{tabular}{|c|c|c|c|}
\hline miRNA & Targets & Mechanism & Reference \\
\hline $\operatorname{miR}-451$ & IL6R & Angiogenesis & [167] \\
\hline $\operatorname{miR}-497$ & $\begin{array}{l}\text { RPTOR independent companion of } \\
\text { MTOR (RICTOR) }\end{array}$ & proliferation, migration and invasion & [168] \\
\hline $\operatorname{miR}-495$ & IGF1R & Proliferation, invasion & [169] \\
\hline $\operatorname{miR}-539$ & Fascin actin-bundling protein 1 (FSCN1) & Migration, invasion & [170] \\
\hline $\operatorname{miR}-638$ & $\begin{array}{l}\text { SRY-box transcription factor } 2 \text { (SOX2), } \\
\text { VEGF }\end{array}$ & Invasion, EMT, angiogenesis & {$[171,172]$} \\
\hline miR-663a & HMGA2 & Proliferation, invasion & [173] \\
\hline $\operatorname{miR}-874$ & $\delta$ opioid receptor (DOR) & Proliferation, metastasis & [174] \\
\hline miR-940 & $\begin{array}{l}\text { C-X-C motif chemokine receptor } 2 \\
\text { (CXCR2) }\end{array}$ & Migration, invasion & [175] \\
\hline $\operatorname{miR}-1271-5 p$ & FOXK2 & Cell growth & [176] \\
\hline miR-1299 & CDK6 & Proliferation & {$[177]$} \\
\hline $\operatorname{miR}-1301$ & BCL9, $\beta$-catenin, VEGFA & Migration, invasion, angiogenesis & [178] \\
\hline
\end{tabular}

\subsection{Development of HCC}

\subsubsection{Oncogenic miRNAs}

miR-21, an oncomiR, is frequently overexpressed in various cancer types, such as breast, lung, prostate, stomach, colon, pancreas, prostate, and liver cancers $[179,180]$. It plays key roles in liver diseases, including viral hepatitis, NAFLD, ALD, liver fibrosis, and HCC [181], and has been shown to induce fibrogenesis in muscles and some organs, such as the heart, lungs, and kidneys [182]. In the liver, it promotes collagen synthesis in the extracellular matrix and fibrosis by activating HSCs, resulting in hepatocarcinogenesis as mentioned in Section 3.3 [62-65]. Clinical data revealed increased miR-21 expression in both tissues and serum of patients with HCC [181,183], and its expression level was significantly correlated with tumor progression [184]. In an in vitro study, miR-21 overexpression promoted cell migration and invasion of HCC by tumor suppressor targeting kruppel-like factor 5 (KLF5) [110]. Another study demonstrated that HCC cells secreted exosomal miRNA-21, which promoted activation of pyruvate dehydrogenase kinase 1 (PDK1)/AKT signaling in HSC s by directly targeting PTEN; PDK1/AKT signaling activation, and promoted cancer progression by causing HCC cells to secrete angiogenic molecules including vascular endothelial growth factor (VEGF), basic fibroblast growth factor (bFGF), matrix metallopeptidase 2 (MMP2), MMP9, and TGF- $\beta$ [185]. Further, a positive correlation was discovered between miR-21 and high-mobility group box (HMGB), a prototypical damage-associated molecular pattern (DAMP) protein, in HCC cell lines and tissues: HMGB1-upregulated miR-21 expression was shown to depend on the IL-6/STAT3 signaling axis in human HCC [186].

miR-155 is involved in inflammatory liver diseases such as HBV infection and NASH [58,59,92], resulting in increased tumorigenicity [187]. miR-155 mainly functions as an oncomiR by targeting tumor suppressors including SOCS1, tumor protein p53 inducible nuclear protein 1 (TP53INP1), CDC73, von Hippel-Lindau tumor suppressor (VHL), and mutL homolog 1 (MLH1). Moreover, the upregulation of miR-155 increases cell proliferation by activating the Wnt/ $\beta$-catenin, AKT, NF-kB, and JAK2/STAT3 signaling pathways. Interestingly, it has been reported that miR-155 plays a tumor-suppressive role and omcomiR under different circumstances such as the time of tumor progression. miR-155 acts as a tumor suppressor in human carcinoma by regulating claudin (CLDN) 1 and SMAD2 [188]. In an in vivo study, miR-155 activated STAT3 signaling by targeting SOCS1, leading to MMP9 production and increased HCC invasion [189].

miR-221 is one of the most highly expressed miRNAs in HCC tissues; its overexpression increases the tumorigenicity of p53-/- myc-expressing liver progenitor cells. Further, miR-221 overexpression stimulates growth of tumorigenic murine hepatic progenitor cells targeting DNA damage-inducible 
transcript 4 (DDIT4), a modulator of mTOR pathway [190]. miR-221 is also associated with apoptosis by targeting tumor suppressors such as PTEN and TIMP3 by activating the AKT pathway and metallopeptidase expression in HCC [30]. Recently, anticancer effects have been demonstrated by positively regulating PTEN, then inactivating the PI3K/AKT signaling pathway by downregulating miR-221 expression, thereby inducing apoptosis of HCC cells [120].

\subsubsection{Tumor Suppressive miRNAs}

The let-7 family comprises of multiple tumor-suppressive miRNAs that target the RAS family, whose functions have been elucidated $[179,191]$. Further, they are antifibrotic miRNAs and are components of central miRNAs involved in transcriptional regulation by PPAR $\gamma$. These miRNAs control the expression of genes related to hepatic fibrosis, resulting in decreased tumorigenicity $[80,192]$. Notably, expression of the let-7 family was downregulated in HCV-associated HCC [193]; let-7g was remarkably downregulated in HCC with metastasis relative to HCC without metastasis. Further, higher let-7g expression in HCC tissues compared with that in non-HCC tissues was significantly associated with good prognosis in HCC patients [193].

The miR-15 family comprises miR-15a, miR-15b, miR-16, miR-195, and miR-497, all of which share the same seed sequence and target specific mRNAs that have complementary sequences. In human HCC, the miR-15 family is downregulated, acting as a tumor suppressor, and plays a key role in modulating hepatic inflammation by directly targeting I kappa B kinase (IKK) $\alpha$ and TGF $\beta$ activated kinase 1 binding protein 3 (TAB3), upstream regulators of the NF- $\mathrm{kB}$ signaling pathway [150]. miR-195 inhibits angiogenesis by directly targeting VEGF, Vav guanine nucleotide exchange factor 2 (VAV2), and cell division cycle 42 (CDC42) in HCC cells [151]. A recent study demonstrated that miR-497 regulated the protein kinase $\mathrm{B}$ (PKB) signaling pathway by targeting Rictor in HCC cells and inhibited proliferation, invasion, metastasis, and chemoresistance of hepatoma cells via the Rictor/AKT signaling pathway [168].

miR-29 plays an important role as a tumor-suppressive miRNA in various cancers and has been shown to modulate some oncogenic processes such as epigenetic processes, proliferation, apoptosis, fibrosis, angiogenesis, immune response, and metastasis [194]. In an in vivo HCC study, miR-29 overexpression induced apoptosis and notably inhibited tumorigenicity by directly targeting antiapoptotic proteins, such as BCL2 and MCL1 [195]. In human HCC in vivo, miR-101, which targets MCL1, is downregulated, thereby inducing apoptosis and retarding tumor development [196]. Further, as a tumor suppressor, miR-101 targets RHO-associated protein kinase (ROCK); ROCK is an important downstream effector of RhoA GTPase, which regulates actomyosin bundles and focal adhesions that inhibit the epithelial-mesenchymal transition (EMT) and angiogenesis. ROCK2 is frequently overexpressed in HCC and its stable overexpression confers cell motility and invasiveness in vitro and in vivo [197].

miR-122 plays a pivotal role not only in lipid metabolism and HCV replication but also in hepatocarcinogenesis. miR-122 has been demonstrated as a tumor suppressor in various cancers, including HCC, and directly targets cyclin G1. In mice, miR-122-knockout resulted in steatohepatitis and carcinogenesis, with most genetic changes associated with the regulation of lipid metabolism, inflammation, and fibrosis [54]. miR-122 has been reported to be significantly suppressed in HCC tissue and cell lines and target IGF-1R, ADAM10, and pyruvate kinase M2 (PKM2) [198]. Moreover, it is demonstrated that the restoration of miR-122 in HCC cells reverses the tumorigenic properties and prevents HCC development in mice [198].

\section{2. miRNAs as Biomarkers for HCC}

The prognoses of patients with HCC remain some of the worst among all cancers, and many patients are already at an advanced stage by diagnosis. Tumor markers are widely used to screen for HCC in high-risk patients; these include $\alpha$-fetoprotein (AFP) and protein induced by vitamin $\mathrm{K}$ absence or antagonists-II (PIVKA-II). However, diagnosis of HCC using conventional tumor markers 
has yielded unsatisfactory results: the sensitivity and specificity for differentiation of HCC were 39-64\% and $76-91 \%$ for AFP, and $41-77 \%$ and $72-98 \%$ for PIVKA-II, respectively [199]. Therefore, additional complementary biomarkers are needed, particularly those associated with early HCC.

Numerous studies have supported the use of several miRNAs as diagnostic and predictive biomarkers in HCC. Circulating miRNAs exist stably in peripheral blood [200], and are thus more useful biomarkers for evaluation of HCC. miRNAs released from cancer cells and tissues exist in the exosome-encapsulated form, apoptotic bodies, or are bound to serum proteins or lipids [201]. Notably, because blood samples can be obtained noninvasively and repeatedly, and because miRNAs exhibit tissue specificity, circulating miRNAs in serum or exosomes may be more useful biomarkers than those in tissues. Various miRNA signatures as biomarkers for HCC have been recently identified (Table 4).

The potential utility of circulating miR-122 and let-7 in early-stage HCC diagnosis has been reported, with comparable sensitivity to that of AFP based on serum levels in HBV patients with precancerous nodules and early HCC [202]. Serum miR-101 expression was significantly downregulated in patients with HBV-associated HCC, relative to those with HBV-associated liver cirrhosis and chronic hepatitis, indicating that miR-101 is a potential biomarker for diagnosing and distinguishing HBV-associated HCC [203]. miR223-3p and miR-125b-5p have shown potential as effective biomarkers in HBV-associated HCC [204]. In contrast, miR-122 may be a useful biomarker in HCV-associated HCC; screening of miR-122, miR-885-5p, miR-221, and miR-22 revealed that miR-122 demonstrated high diagnostic accuracy for detection of early HCC in liver cirrhosis patients [205]. We previously reported the efficacy of miR-125a-5p as a diagnostic biomarker for HCV-associated HCC [108]. The expression level of certain miRNAs depends on progress of HCC; low miR-296 expression in HCC patients was associated with large tumor size and advanced clinical stage [159]. Similarly, low miR-137 expression was associated with the presence of lymph node metastasis or vascular invasion in HCC [143].

Several miRNAs have demonstrated potential utility as predictive biomarkers of HCC prognosis. Recent studies have shown that high expression of miR-92a, miR-221, miR-487a, or miR-1468 was associated with poor prognosis in HCC patients $[113,126,131,206]$. In contrast, downregulation of miR-33a, miR-137, miR-194, or miR-940 led to poor prognosis in HCC [143,149,175,207]. High expression of exosomal miR-32-5p, which targets PTEN, indicated poor prognosis of HCC patients [208]. Lower expression of exosomal miR-638 was associated with poorer overall survival among HCC patients [209]. Further, miR-122, miR-148a, and miR-1246 expression levels were significantly higher in serum exosomes from HCC patients than in those from liver cirrhosis patients and healthy controls [210].

Table 4. Recently reported miRNAs as biomarkers for HCC.

\begin{tabular}{ccccc}
\hline & miRNA & Expression & Background & Reference \\
\hline \multirow{4}{*}{ Diagnosis } & let-7 & up & HBV infection & {$[202]$} \\
& miR-101 & down & HBV infection & {$[203]$} \\
& miR-122 & up & HBV infection, HCV infection & {$[202,205]$} \\
& miR-125a-5p & up & HBV infection, HCV infection & {$[204]$} \\
miR-223-3p & down & HBV infection & {$[204]$} \\
\hline miR-32-5p & up & HBV infection and others & {$[208]$} \\
miR-33a & down & Unknown & {$[207]$} \\
miR-92a & up & HBV infection and others & {$[113]$} \\
miR-122 & up & HBV infection, HCV infection & {$[210]$} \\
& miR-137 & down & HBV infection and others & {$[143]$} \\
& miR-148a & up & HBV infection, HCV infection & {$[210]$} \\
miR-194 & down & Unknown & {$[149]$} \\
miR-221 & up & HBV infection and others & {$[206]$} \\
miR-296 & down & HBV infection and others & {$[159]$} \\
miR-487a & up & HBV infection and others & {$[126]$} \\
& miR-638 & down & HBV infection, HCV infection & {$[209]$} \\
& miR-940 & down & HBV infection and others & {$[175]$} \\
miR-1246 & up & HBV infection, HCV infection & {$[210]$} \\
miR-1468 & up & HBV infection and others & {$[131]$} \\
\hline
\end{tabular}




\section{3. miRNAs as Therapeutic Targets for HCC}

Several miRNAs have been shown to regulate multiple targets in HCC-related cascades, and miRNA-based cancer therapy is attractive for the development of more practical strategies. There are currently two miRNA-based strategies for HCC, namely (1) replacement or overexpression of HCC-specific miRNAs using mimics and (2) suppression or downregulation of HCC-specific miRNAs using antagonists. In replacement therapy, the deleted or downregulated miRNAs in HCC are restored; this can suppress the translation of pivotal mRNAs that inhibit proliferation or promote apoptosis in HCC cells [211]. Conversely, specifically overexpressed miRNAs in HCC can be inactivated by antagonists in miRNA suppression therapy [212]. However, when nucleic acids such as miRNAs are directly administered, sufficient gene knockdown effects cannot be obtained due to poor cell membrane permeability and nuclease degradation. Therefore, miRNA oligomers are used to regulate miRNA dysfunctions, including antimiRNA oligonucleotides (AMOs), locked-nucleic-acid antisense oligonucleotides (LNAs), miRNA sponges, miRNA masks, nanoparticles, antagomirs, and multiple-target antimiRNA antisense oligodeoxyribonucleotides (MTg-AMOs) [213,214]. The potential therapeutic applications of miRNA targeting have received increasing attention in HCC research.

The delivery of small RNAs, such as miRNA inhibitors or precursors, can be achieved using adeno-associated virus (AAV) vectors. Remarkably, using AAV vectors for delivery of miR-26a, which is lowly expressed in HCC tissues and highly expressed in normal liver tissues, aided suppression of HCC development; further, miR-26a replacement in HCC cells induced cell-cycle arrest by directly targeting cyclin D2 and E2 [215]. In fact, systemic administration of miR-26a using AVV vectors in an HCC mouse model resulted in dramatic protection against HCC progression by inhibiting cell proliferation and inducing apoptosis without toxicity [215].

LNP-DP1, a cationic lipid nanoparticle formulation, is a useful vehicle to restore dysregulated genes in HCC cells by delivering miR-122, which is often downregulated in HCC cells and tissues. In an in vitro study, the LNP-DP1-mediated transfection of miR-122 downregulated more than $95 \%$ of the target genes in HCC cells. In an in vivo study, LNP-DP1-mediated siRNAs and miRNAs were effectively taken up by HCC cells; further, LNP-DP1-mediated delivery of the miR-122 mimic suppressed HCC development by regulating target genes and impairing angiogenesis, without systemic toxicity [216].

\section{4. miRNAs in HCC Therapy Resistance}

Current drug therapies for HCC include the chemotherapeutic drugs cisplatin, doxorubicin, and 5-FU, and the molecular-targeted drugs sorafenib, regorafenib, and lenvatinib [217]. Drug therapy for HCC has made great progress in recent decades, but drug resistance is a major cause of treatment failure. Drug resistance is associated with increases in drug efflux, target switching, cell-cycle checkpoint alteration, increased antiapoptotic signals, and DNA damage repair [218]. Many recent studies have indicated that miRNAs affect HCC drug resistance by influencing genes associated with cell proliferation and apoptosis. Elucidating the mechanism of drug resistance acquisition against HCC via miRNAs will help predict drug susceptibility, develop better therapeutic strategies to overcome drug resistance, and improve treatment outcomes for HCC patients. Various miRNA signatures in HCC therapy resistance have been recently identified (Table 5).

Cisplatin, a first-generation platinum chemotherapeutic drug, is a broad-spectrum anticancer drug that binds to DNA required for the proliferation of cancer cells, causing DNA replication and cancer cell self-destruction. Studies have suggested various relationships between miRNAs and cisplatin. In ovarian cancer cells, miR-214 induced cisplatin resistance by negatively regulating PTEN [219], while miR-33a-5p might induce cisplatin resistance via SOCS3 in HCC cells [220]. Therefore, suppressing miR-33a-5p is one of the potential therapeutic strategies to mediate the cisplatin resistance of HCC cells [221]. The comprehensive review by Jones et al. [222] indicated that multiple oncogenes, including miR-130a and miR-182, are significantly elevated both in HCC tissues and cell lines, and promote cisplatin resistance. Further, changes in the expression of miR-96, miR-130a, 
miR-182, miR-199a, and miR-340 either increased or reduced sensitivity of HCC to cisplatin [14]. Interestingly, miR-363 was shown to be significantly downregulated in cisplatin-resistant HCC cell lines compared to parental cells, and transfection of miR-363 increased the sensitivity of cisplatin-resistant HCC cells to cisplatin-induced apoptosis by targeting antiapoptotic protein MCL1 [223].

Doxorubicin and 5-FU are classic chemotherapeutic drugs used mainly for transcatheter arterial infusion (TAI). ATP-binding cassette (ABC) transporter protein causes tumor sensitivity and resistance; miR-133a and miR-326 target $A B C$ subfamily $C 1$, increasing the sensitivity of HCC cells to doxorubicin [224]. miR-141 expression was higher in 5-FU-resistant cells than in parental cells [225] due to the downregulation of Kelch-like ECH-associated protein 1 (KEAP1) expression and reactivation of nuclear factor erythroid 2 like 2 (NFE2L2)-dependent antioxidant pathways. Notably, several oncogenic miRNAs, such as miR-200a-3p, miR-183, miR-141, and miR-193a-3p, can promote 5-FU resistance; miR-200a-3p enhanced HCC 5-FU-resistance by suppressing the expression of dual-specificity phosphatase 6 (DUSP6) [225-227]. In contrast, some tumor-suppressive miRNAs are associated with reducing 5-FU resistance; miRNA-125b and miRNA-195 increased the sensitivity of 5-FU-resistant HCC cells to 5-FU-induced apoptosis by targeting antiapoptotic proteins BCL2 and hexokinase 2 [14]. Notably, some miRNAs increase toxicity; for instance, miR-503 markedly enhanced 5-FU toxicity in HCC by downregulating eukaryotic translation initiation factor 4E (EIF4E) [228].

Sorafenib is a multikinase inhibitor that suppresses proliferation and angiogenesis by targeting v-raf murine sarcoma viral oncogene homolog B (BRAF), RAF1, VEGFR-2/3, and platelet-derived growth factor receptor $\beta$ (PDGFR $\beta$ ). HCC resistance to sorafenib is well known; several oncogenic miRNAs, including miR-93, miR-216a, and miR217, promote sorafenib resistance by targeting p21Cip/Waf1, thereby modulating apoptosis and TGF- $\beta$ signaling [222]. Overexpression of miR-216a/217 acts as a positive feedback regulator for the PI3K/AKT and TGF- $\beta$ pathways by targeting PTEN and SMAD7, resulting in hepatocarcinogenesis and HCC recurrence. Additionally, activation of PI3K/AKT and TGF- $\beta$ signaling contributed to the acquisition of miR-216a/217-induced sorafenib resistance in HCC; conversely, blocking these signals overcame sorafenib resistance and prevented metastases in HCC [229]. In contrast, miR-181 induced sorafenib resistance by suppressing Ras association domain family 1 (RASSF1) [230]. miR-494 increased HCC resistance to sorafenib by modulating PTEN and mTOR signaling [231]. Therefore, concomitant inhibition of miR-181 or miR-494 during sorafenib treatment enhances the sensitivity of HCC to sorafenib, thus indicating that these miRNAs may act as potential therapeutic targets for refractory drug-resistant HCC.

Table 5. Recently reported miRNAs in HCC therapy resistance.

\begin{tabular}{|c|c|c|c|}
\hline Drug & miRNA & Target & Reference \\
\hline \multirow{2}{*}{ Cisplatin } & miR-33a-5p & SOCS3 & {$[220,221]$} \\
\hline & $\mathrm{miR}-363$ & MCL1 & [223] \\
\hline \multirow{2}{*}{ Doxorubicin } & miR-133a & ABC subfamily $\mathrm{C} 1$ & [224] \\
\hline & miR-326 & ABC subfamily $\mathrm{C} 1$ & [224] \\
\hline \multirow{6}{*}{ 5-FU } & & Kelch-like ECH-associated & \\
\hline & miR-141 & protein 1 (KEAP1), & [225] \\
\hline & & $\begin{array}{l}\text { Nuclear factor erythroid } 2 \text { 11ke } 2 \\
\text { (NFE2L2) }\end{array}$ & \\
\hline & $\operatorname{miR}-125 b$ & BCL2 & [14] \\
\hline & miR-195 & BCL2 & {$[14]$} \\
\hline & miR-503 & $\begin{array}{l}\text { eukaryotic translation initiation } \\
\text { factor } 4 \mathrm{E} \text { (EIF4E) }\end{array}$ & [228] \\
\hline \multirow{5}{*}{ Sorafenib } & miR-93 & p21Cip/Waf1 & [222] \\
\hline & $\operatorname{miR}-181$ & $\begin{array}{l}\text { Ras association domain family } 1 \\
\text { (RASSF1) }\end{array}$ & [230] \\
\hline & miR-216a & p21Cip/Waf1 & [222] \\
\hline & $\operatorname{miR}-217$ & p21Cip/Waf1 & [222] \\
\hline & $\operatorname{miR}-494$ & PTEN, mTOR & [231] \\
\hline
\end{tabular}




\section{Conclusions}

The biological significance and utility of miRNAs in liver disease, especially in HCC, is a rapidly growing field. Accumulating evidence has demonstrated that many miRNAs play regulatory roles in many biological processes associated with HCC, including oncogenesis, tumor development, cell proliferation, and apoptosis. In this article, we reviewed the molecular and functional roles of miRNAs in the development and progression of HCC. Many studies have investigated aberrant miRNA processing and miRNA expression profiles in HCC, including those of circulating miRNAs, which have contributed to the discovery and clinical adaptation of miRNAs as potential biomarkers for diagnosis (particularly early diagnosis) and as prognostic markers for HCC. Furthermore, investigating their molecular and functional roles is likely to be useful for developing therapeutic targets and understanding resistance to conventional therapies. Although miRNAs do not have a direct antitumor effect on HCC, miRNA-based therapy offers a promising perspective compared to classical gene therapy such as induction of a single gene because miRNA exerts antitumor effects by regulating the expression of multiple genes involved in hepatocarcinogenesis. In addition, miRNAs are generally not immunogenic because they do not encode proteins. A combination of conventional and miRNA-based therapy for HCC may be preferable by offering improved gene transfer efficiency and transgene expression.

Although miRNAs have demonstrated potential as biological targets for HCC treatment in preclinical studies, miRNA-based therapy is not yet suitable for clinical practice. Some important problems need to be resolved before clinical application. The first is that due to tumor cell heterogeneity, miRNAs exert different regulatory effects in different types of tumors, and may even show opposite results in different studies. The second is that in vivo research with miRNAs is still relatively scarce; miRNA regulation in vivo may not always be observed due to the complexity of the in-vivo environment. Therefore, extensive in vivo confirmation of miRNA roles in the progression of HCC and their therapeutic effects is required. Finally, because miRNAs are large molecules, further research is needed to effectively administer and deliver miRNAs into tumor cells in the body. Ongoing global miRNA research will be useful for understanding the current state of clinical miRNA application, and for elucidating the biological characteristics underlying diagnosis, treatment, pathology, and prognosis prediction in HCC.

Author Contributions: K.O. and T.M. conceived and designed the study. K.O. and A.M. performed the data collection and analyzed the data. K.O., A.M., and T.M. wrote the paper. All authors have read and agreed to the published version of the manuscript.

Funding: This research received no external funding.

Conflicts of Interest: The authors declare no conflict of interest.

$\begin{array}{ll}\text { Abbreviations } & \\ \text { HCC } & \text { Hepatocellular carcinoma } \\ \text { miRNA } & \text { MicroRNA } \\ \text { siRNA } & \text { Small interfering RNA } \\ \text { priRNA } & \text { PIWI-Interacting RNA } \\ \text { mRNA } & \text { Messenger RNA } \\ \text { HBV } & \text { Viral hepatitis B } \\ \text { HCV } & \text { Viral hepatitis C } \\ \text { ALD } & \text { Alcoholic liver disease } \\ \text { NAFLD } & \text { Nonalcoholic fatty liver disease } \\ \text { UTR } & \text { Untranslated region } \\ \text { pri-miRNA } & \text { Primary microRNA } \\ \text { DGCR8 } & \text { DiGeorge syndrome critical region gene 8 } \\ \text { TRBP } & \text { Transactivation response element RNA-binding protein } \\ \text { RISC } & \text { RNA-Induced silencing complex } \\ \text { AGO } & \text { Argonaute protein }\end{array}$




\begin{tabular}{|c|c|}
\hline OncomiR & Oncogenic miRNA \\
\hline IL-6 & Interleukin-6 \\
\hline TNF- $\alpha$ & Tumor necrosis factor- $\alpha$ \\
\hline HGF & Hepatocyte growth factor \\
\hline PTEN & Phosphatase and tensin homolog deleted on chromosome \\
\hline RhoB & Ras homolog family member B \\
\hline PI3K & Phosphoinositide 3-kinase \\
\hline mTOR & Mammalian target of rapamycin \\
\hline SMAD3 & Small mother against decapentaplegic 3 \\
\hline TRAIL & TNF related apoptosis-inducing ligand \\
\hline PUMA & P53 upregulated modulator of apoptosis \\
\hline STAT3 & Signal transducer and activator of transcription 3 \\
\hline TIMP3 & Tissue inhibitor of metalloproteinase 3 \\
\hline NASH & Nonalcoholic steatohepatitis \\
\hline FASN & Fatty acid synthase \\
\hline ACC1 & Acetyl-CoA carboxylase 1 \\
\hline IGF & Insulin-like growth factor \\
\hline HNF & Hepatocyte nuclear factor \\
\hline AMPK & Adenosine $5^{\prime}$-monophosphate-activated protein kinase \\
\hline SIRT1 & Sirtuin 1 \\
\hline PPAR & Peroxisome proliferator activated receptor \\
\hline LXR & Liver $X$ receptor \\
\hline SREBP & Sterol regulatory element-binding protein \\
\hline HSC & Hepatic stellate cell \\
\hline TGF & Transforming growth factor \\
\hline ADAM17 & A disintegrin and metalloproteinase 17 \\
\hline TLR2 & Toll-Like receptor 2 \\
\hline WNT & Wingless-Related integration site \\
\hline JAK & Janus kinase \\
\hline MAPK & Mitogen-Activated protein kinase \\
\hline SOCS3 & Suppressor of cytokine signaling 3 \\
\hline HBe & Hepatitis Be \\
\hline SHIP1 & SH2-Containg inositol phosphatase 1 \\
\hline ULK1 & Unc-51 like autophagy activating kinase 1 \\
\hline PCBP & Poly(rC)-Binding protein \\
\hline DLC & Deleted in liver cancer \\
\hline IRF1 & Interferon regulatory factor 1 \\
\hline FN & Fibronectin \\
\hline SCD & Stearoyl-CoA desaturase \\
\hline CREB1 & cAMP responsive element binding protein 1 \\
\hline TRIF & TIR-Domain-Containing adapter-inducing interferon \\
\hline HMGA2 & High-Mobility group AT-hook 2 \\
\hline C/EBP & CCAAT/enhancer binding protein \\
\hline KLF5 & Kruppel-Like factor 5 \\
\hline PDK1 & Pyruvate dehydrogenase kinase 1 \\
\hline VEGF & Vascular endothelial growth factor \\
\hline bFGF & Basic fibroblast growth factor \\
\hline MMP2 & Matrix metallopeptidase 2 \\
\hline HMGB & High-Mobility group box \\
\hline DAMP & Damaged-Associated molecular pattern \\
\hline TP53INP1 & Tumor protein p53 inducible nuclear protein 1 \\
\hline VFL & von Hippel-Lindau tumor suppressor \\
\hline MLH1 & MutL homolog 1 \\
\hline
\end{tabular}




$\begin{array}{ll}\text { CLDN } & \text { Claudin } \\ \text { DDIT } & \text { DNA damage-inducible transcript } \\ \text { IKK } & \text { I kappa B kinase } \\ \text { TAB3 } & \text { TGF-beta activated kinase 1 binding protein 3 } \\ \text { VAV2 } & \text { Vav guanine nucleotide exchange factor 2 } \\ \text { CDC42 } & \text { Cell division cycle 42 } \\ \text { PKB } & \text { Protein kinase B } \\ \text { ROCK } & \text { RHO-Associated protein kinase } \\ \text { EMT } & \text { Epithelial-Mesenchymal transition } \\ \text { PKM2 } & \text { Pyruvate kinase M2 } \\ \text { AFP } & \alpha \text {-fetoprotein } \\ \text { PIVKA-II } & \text { Vitamin K absence or antagonists-II } \\ \text { AMO } & \text { AntimiRNA oligonucleotide } \\ \text { LNA } & \text { Locked-Nucleic-Acid antisense oligonucleotide } \\ \text { MTg-AMO } & \text { Antagomirs and multiple-target antimiRNA antisense oligodeoxyribonucleotide } \\ \text { AAV } & \text { Adeno-Associated virus } \\ \text { TAI } & \text { Transcatheter arterial infusion } \\ \text { ABC } & \text { ATP-Binding cassette } \\ \text { KEAP1 } & \text { Kelch-Like ECH-associated protein 1 } \\ \text { NFE2L2 } & \text { Nuclear factor erythroid 2 like 2 } \\ \text { DUSP6 } & \text { Dual specificity phosphatase 6 } \\ \text { EIF4E } & \text { Eukaryotic translation initiation factor 4E } \\ \text { BRAF } & \text { v-Raf murine sarcoma viral oncogene homolog B } \\ \text { PDGFR3 } & \text { Platelet-Derived growth factor receptor 3 } \\ \text { RASSF1 } & \text { Ras association domain family member 1 } \\ & \end{array}$

\section{References}

1. Global Burden of Disease Cancer Collaboration; Fitzmaurice, C.; Allen, C.; Barber, R.M.; Barregard, L.; Bhutta, Z.A.; Brenner, H.; Dicker, D.J.; Chimed-Orchir, O.; Dandona, R.; et al. Global, regional, and national cancer incidence, mortality, years of life lost, years lived with disability, and disability-adjusted life-years for 32 cancer groups, 1990 to 2015: A systematic analysis for the global burden of disease study. JAMA Oncol. 2017, 3, 5245-5248.

2. El-Serag, H.B.; Rudolph, K.L.L. Hepatocellular carcinoma: Epidemiology and molecular carcinogenesis. Gastroenterology 2007, 132, 2557-2576. [CrossRef] [PubMed]

3. Yang, J.D.; Hainaut, P.; Gores, G.J.; Amadou, A.; Plymoth, A.; Roberts, L.R.R. A global view of hepatocellular carcinoma: Trends, risk, prevention and management. Nat. Rev. Gastroenterol. Hepatol. 2019, 16, 589-604. [CrossRef] [PubMed]

4. Park, J.W.; Chen, M.; Colombo, M.; Roberts, L.R.; Schwartz, M.; Chen, P.J.; Kudo, M.; Johnson, P.; Wagner, S.; Orsini, L.S.; et al. Global patterns of hepatocellular carcinoma management from diagnosis to death: The BRIDGE Study. Liver Int. 2015, 35, 2155-2166. [CrossRef]

5. Younossi, Z.M.; Blissett, D.; Blissett, R.; Henry, L.; Stepanova, M.; Younossi, Y.; Racila, A.; Hunt, S.; Beckerman, R.R. The economic and clinical burden of nonalcoholic fatty liver disease in the United States and Europe. Hepatology 2016, 64, 1577-1586. [CrossRef]

6. Altekruse, S.F.; Henley, S.J.; Cucinelli, J.E.; McGlynn, K.A.A. Changing hepatocellular carcinoma incidence and liver cancer mortality rates in the United States. Am. J. Gastroenterol. 2014, 109, 542-553. [CrossRef] [PubMed]

7. Zhang, G.; Li, R.; Deng, Y.; Zhao, L.L. Conditional survival of patients with hepatocellular carcinoma: Results from the Surveillance, Epidemiology, and End Results registry. Expert Rev. Gastroenterol. Hepatol. 2018, 12, 515-523. [CrossRef]

8. Xu, L.; Kim, Y.; Spolverato, G.; Gani, F.; Pawlik, T.M.M. Racial disparities in treatment and survival of patients with hepatocellular carcinoma in the United States. Hepatobiliary Surg. Nutr. 2016, 5, 43-52.

9. Esquela-Kerscher, A.; Slack, F.J.J. Oncomirs-microRNAs with a role in cancer. Nat. Rev. Cancer 2006, 6, 2596-2599. [CrossRef] 
10. Bartel, D.P.P. MicroRNAs: Genomics, biogenesis, mechanism, and function. Cell 2004, 116, $281-297$. [CrossRef]

11. Kim, V.N.N. MicroRNA biogenesis: Coordinated cropping and dicing. Nat. Rev. Mol. Cell Biol. 2005, 6, 376-385. [CrossRef] [PubMed]

12. Borchert, G.M.; Lanier, W.; Davidson, B.L.L. RNA polymerase III transcribes human microRNAs. Nat. Struct. Mol. Biol. 2006, 13, 1097-1101. [CrossRef]

13. Garzon, R.; Fabbri, M.; Cimmino, A.; Calin, G.A.; Croce, C.M.M. MicroRNA expression and function in cancer. Trends Mol. Med. 2006, 12, 580-587. [CrossRef] [PubMed]

14. Si, W.; Shen, J.; Zheng, H.; Fan, W.W. The role and mechanisms of action of microRNAs in cancer drug resistance. Clin. Epigenetics 2019, 11, 25. [CrossRef]

15. Cheng, C.J.; Slack, F.J.J. The duality of oncomiR addiction in the maintenance and treatment of cancer. Cancer J. 2012, 18, 232-237. [CrossRef]

16. Nedaeinia, R.; Manian, M.; Jazayeri, M.H.; Ranjbar, M.; Salehi, R.; Sharifi, M.; Mohaghegh, F.; Goli, M.; Jahednia, S.H.; Avan, A.; et al. Circulating exosomes and exosomal microRNAs as biomarkers in gastrointestinal cancer. Cancer Gene Ther. 2017, 24, 48-56. [CrossRef]

17. Zheng, Q.; Chen, C.; Guan, H.; Kang, W.; Yu, C.C. Prognostic role of microRNAs in human gastrointestinal cancer: A systematic review and meta-analysis. Oncotarget 2017, 8, 46611-46623. [CrossRef]

18. Santoni, G.; Morelli, M.B.; Amantini, C.; Battelli, N.N. Urinary markers in bladder cancer: An update. Front. Oncol. 2018, 8, 362. [CrossRef]

19. Wang, J.; Ni, J.; Beretov, J.; Thompson, J.; Graham, P.; Li, Y.Y. Exosomal microRNAs as liquid biopsy biomarkers in prostate cancer. Crit. Rev. Oncol. Hematol. 2020, 145, 102860. [CrossRef]

20. Miao, J.; Regenstein, J.M.; Xu, D.; Zhou, D.; Li, H.; Zhang, H.; Li, C.; Qiu, J.; Chen, X.X. The roles of microRNA in human cervical cancer. Arch. Biochem. Biophys. 2020, 690, 108480. [CrossRef]

21. Wadowska, K.; Bil-Lula, I.; Trembecki, L.; Sliwinska-Mosson, M.M. Genetic markers in lung cancer diagnosis: A review. Int. J. Mol. Sci. 2020, 21, 4569. [CrossRef]

22. Xu, J.; An, P.; Winkler, C.A.; Yu, Y.Y. Dysregulated microRNAs in hepatitis B virus-related hepatocellular carcinoma: Potential as biomarkers and therapeutic targets. Front. Oncol. 2020, 10, 1271. [CrossRef]

23. Lim, L.J.; Wong, S.Y.S.; Huang, F.; Lim, S.; Chong, S.S.; Ooi, L.L.; Kon, O.L.; Lee, C.G.G. Roles and regulation of long noncoding RNAs in hepatocellular carcinoma. Cancer Res. 2019, 79, 5131-5139. [CrossRef]

24. Fausto, N.; Campbell, J.S.; Riehle, K.J.J. Liver regeneration. Hepatology 2006, 43 (Suppl. 1), S45-S53. [CrossRef]

25. Shu, J.; Kren, B.T.; Xia, Z.; Wong, P.Y.; Li, L.; Hanse, E.A.; Min, M.X.; Li, B.; Albrecht, J.H.; Zeng, Y.; et al. Genomewide microRNA down-regulation as a negative feedback mechanism in the early phases of liver regeneration. Hepatology 2011, 54, 609-619. [CrossRef]

26. Chen, X.; Murad, M.; Cui, Y.Y.; Yao, L.J.; Venugopal, S.K.; Dawson, K.; Wu, J.J. miRNA regulation of liver growth after 50\% partial hepatectomy and small size grafts in rats. Transplantation 2011, 91, 293-399. [CrossRef] [PubMed]

27. Yan-nan, B.; Zhao-yan, Y.; Li-xi, L.; Jiang, Y.; Qing-jie, X.; Yong, Z.Z. MicroRNA-21 accelerates hepatocyte proliferation in vitro via PI3K/Akt signaling by targeting PTEN. Biochem. Biophys. Res. Commun. 2014, 443, 802-807. [CrossRef]

28. Chen, X.; Song, M.; Chen, W.; Dimitrova-Shumkovska, J.; Zhao, Y.; Cao, Y.; Song, Y.; Yang, W.; Wang, F.; Xiang, Y.; et al. MicroRNA-21 contributes to liver regeneration by targeting PTEN. Med. Sci. Monit. 2016, 22, 83-91. [CrossRef]

29. Lv, T.; Kong, L.; Jiang, L.; Wu, H.; Wen, T.; Shi, Y.; Yang, J.J. Dicer1 facilitates liver regeneration in a manner dependent on the inhibitory effect of miR-21 on Pten and Rhob expression. Life Sci. 2019, 232, 116656. [CrossRef]

30. Yuan, B.; Dong, R.; Shi, D.; Zhou, Y.; Zhao, Y.; Miao, M.; Jiao, B.B. Down-regulation of miR-23b may contribute to activation of the TGF-beta1/Smad3 signalling pathway during the termination stage of liver regeneration. FEBS Lett. 2011, 585, 9273-9274. [CrossRef]

31. Chen, H.; Sun, Y.; Dong, R.; Yang, S.; Pan, C.; Xiang, D.; Miao, M.; Jiao, B.B. Mir-34a is upregulated during liver regeneration in rats and is associated with the suppression of hepatocyte proliferation. PLOS ONE 2011, 6, e20238. [CrossRef] [PubMed]

32. Yi, P.S.; Zhang, M.; Xu, M.Q.Q. Role of microRNA in liver regeneration. Hepatobiliary Pancreat. Dis. Int. 2016, 15, 141-146. [CrossRef] 
33. Shirjang, S.; Mansoori, B.; Asghari, S.; Duijf, P.H.G.; Mohammadi, A.; Gjerstorff, M.; Baradaran, B.B. MicroRNAs in cancer cell death pathways: Apoptosis and necroptosis. Free Radic. Biol. Med. 2019, 139, 1-15. [CrossRef]

34. An, F.; Gong, B.; Wang, H.; Yu, D.; Zhao, G.; Lin, L.; Tang, W.; Yu, H.; Bao, S.; Xie, Q.Q. miR-15b and miR-16 regulate TNF mediated hepatocyte apoptosis via BCL2 in acute liver failure. Apoptosis 2012, 17, 702-716. [CrossRef] [PubMed]

35. Zhang, Y.; Huang, F.; Wang, J.; Peng, L.; Luo, H.H. MiR-15b mediates liver cancer cells proliferation through targeting BCL-2. Int. J. Clin. Exp. Pathol. 2015, 8, 15677-15683.

36. Gong, J.; Zhang, J.P.; Li, B.; Zeng, C.; You, K.; Chen, M.X.; Yuan, Y.; Zhuang, S.M.M. MicroRNA-125b promotes apoptosis by regulating the expression of Mcl-1, Bcl-w and IL-6R. Oncogene 2013, 32, 3071-3079. [CrossRef]

37. Santhekadur, P.K.; Das, S.K.; Gredler, R.; Chen, D.; Srivastava, J.; Robertson, C.; Baldwin, A.S.S., Jr.; Fisher, P.B.; Sarkar, D.D. Multifunction protein staphylococcal nuclease domain containing 1 (SND1) promotes tumor angiogenesis in human hepatocellular carcinoma through novel pathway that involves nuclear factor kappaB and miR-221. J. Biol. Chem. 2012, 287, 13952-13958. [CrossRef]

38. Li, Y.; Di, C.; Li, W.; Cai, W.; Tan, X.; Xu, L.; Yang, L.; Lou, G.; Yan, Y.Y. Oncomirs miRNA-221/222 and tumor suppressors miRNA-199a/195 are crucial miRNAs in liver cancer: A systematic analysis. Dig. Dis. Sci. 2016, 61, 2315-2327. [CrossRef]

39. Garofalo, M.; Di Leva, G.; Romano, G.; Nuovo, G.; Suh, S.S.; Ngankeu, A.; Taccioli, C.; Pichiorri, F.; Alder, H.; Secchiero, P.; et al. miR-221\&222 regulate TRAIL resistance and enhance tumorigenicity through PTEN and TIMP3 downregulation. Cancer Cell 2009, 16, 498-509. [PubMed]

40. Sharma, A.D.; Narain, N.; Handel, E.M.; Iken, M.; Singhal, N.; Cathomen, T.; Manns, M.P.; Scholer, H.R.; Ott, M.; Cantz, T.T. MicroRNA-221 regulates FAS-induced fulminant liver failure. Hepatology 2011, 53, 1651-1661. [CrossRef]

41. Jopling, C.C. Liver-specific microRNA-122: Biogenesis and function. RNA Biol. 2012, 9, 137-742. [CrossRef]

42. Cheung, O.; Puri, P.; Eicken, C.; Contos, M.J.; Mirshahi, F.; Maher, J.W.; Kellum, J.M.; Min, H.; Luketic, V.A.; Sanyal, A.J.J. Nonalcoholic steatohepatitis is associated with altered hepatic MicroRNA expression. Hepatology 2008, 48, 1810-1820. [CrossRef]

43. Wei, S.; Zhang, M.; Yu, Y.; Xue, H.; Lan, X.; Liu, S.; Hatch, G.; Chen, L.L. HNF-4alpha regulated miR-122 contributes to development of gluconeogenesis and lipid metabolism disorders in Type 2 diabetic mice and in palmitate-treated HepG2 cells. Eur. J. Pharm. 2016, 791, 254-263. [CrossRef] [PubMed]

44. Braza-Boils, A.; Mari-Alexandre, J.; Molina, P.; Arnau, M.A.; Barcelo-Molina, M.; Domingo, D.; Girbes, J.; Giner, J.; Martinez-Dolz, L.; Zorio, E.E. Deregulated hepatic microRNAs underlie the association between non-alcoholic fatty liver disease and coronary artery disease. Liver Int. 2016, 36, 1221-1229. [CrossRef]

45. Latorre, J.; Moreno-Navarrete, J.M.; Mercader, J.M.; Sabater, M.; Rovira, O.; Girones, J.; Ricart, W.; Fernandez-Real, J.M.; Ortega, F.J.J. Decreased lipid metabolism but increased FA biosynthesis are coupled with changes in liver microRNAs in obese subjects with NAFLD. Int. J. Obes. (Lond.) 2017, 41, 620-630. [CrossRef]

46. Becker, P.P.; Rau, M.; Schmitt, J.; Malsch, C.; Hammer, C.; Bantel, H.; Mullhaupt, B.; Geier, A.A. Performance of Serum microRNAs -122, -192 and -21 as Biomarkers in Patients with Non-Alcoholic Steatohepatitis. PLoS ONE 2015, 10, e0142661. [CrossRef]

47. Pirola, C.J.; Fernandez Gianotti, T.; Castano, G.O.; Mallardi, P.; San Martino, J.; Mora Gonzalez Lopez Ledesma, M.; Flichman, D.; Mirshahi, F.; Sanyal, A.J.; Sookoian, S.S. Circulating microRNA signature in non-alcoholic fatty liver disease: From serum non-coding RNAs to liver histology and disease pathogenesis. Gut 2015, 64, 8001-8002. [CrossRef]

48. Akuta, N.; Kawamura, Y.; Suzuki, F.; Saitoh, S.; Arase, Y.; Fujiyama, S.; Sezaki, H.; Hosaka, T.; Kobayashi, M.; Suzuki, Y.; et al. Analysis of association between circulating miR-122 and histopathological features of nonalcoholic fatty liver disease in patients free of hepatocellular carcinoma. BMC Gastroenterol. 2016, 16, 141. [CrossRef]

49. Esau, C.; Davis, S.; Murray, S.F.; Yu, X.X.; Pandey, S.K.; Pear, M.; Watts, L.; Booten, S.L.; Graham, M.; McKay, R.; et al. miR-122 regulation of lipid metabolism revealed by in vivo antisense targeting. Cell Metab. 2006, 3, 87-98. [CrossRef] [PubMed] 
50. Salvoza, N.C.; Klinzing, D.C.; Gopez-Cervantes, J.; Baclig, M.O.O. Association of circulating serum miR-34a and miR-122 with dyslipidemia among patients with non-alcoholic fatty liver disease. PLoS ONE 2016, 11, e0153497. [CrossRef] [PubMed]

51. Ding, J.; Li, M.; Wan, X.; Jin, X.; Chen, S.; Yu, C.; Li, Y.Y. Effect of miR-34a in regulating steatosis by targeting PPARalpha expression in nonalcoholic fatty liver disease. Sci. Rep. 2015, 5, 13729. [CrossRef]

52. Wan, Y.; McDaniel, K.; Wu, N.; Ramos-Lorenzo, S.; Glaser, T.; Venter, J.; Francis, H.; Kennedy, L.; Sato, K.; Zhou, T.; et al. Regulation of cellular senescence by miR-34a in alcoholic liver injury. Am. J. Pathol. 2017, 187, 2788-2798. [CrossRef] [PubMed]

53. Rottiers, V.; Naar, A.M.M. MicroRNAs in metabolism and metabolic disorders. Nat. Rev. Mol. Cell Biol. 2012, 13, 239-250. [CrossRef] [PubMed]

54. Hsu, S.H.; Wang, B.; Kota, J.; Yu, J.; Costinean, S.; Kutay, H.; Yu, L.; Bai, S.; La Perle, K.; Chivukula, R.R.; et al. Essential metabolic, anti-inflammatory, and anti-tumorigenic functions of miR-122 in liver. J. Clin. Investig. 2012, 122, 2871-2883. [CrossRef] [PubMed]

55. Wen, J.; Friedman, J.R.R. miR-122 regulates hepatic lipid metabolism and tumor suppression. J. Clin. Investig. 2012, 122, 2773-2776. [CrossRef]

56. Strum, J.C.; Johnson, J.H.; Ward, J.; Xie, H.; Feild, J.; Hester, A.; Alford, A.; Waters, K.M.M. MicroRNA 132 regulates nutritional stress-induced chemokine production through repression of SirT1. Mol. Endocrinol. 2009, 23, 1876-1884. [CrossRef]

57. Bala, S.; Szabo, G.G. MicroRNA signature in alcoholic liver disease. Int. J. Hepatol. 2012, 2012, 498232. [CrossRef]

58. Momen-Heravi, F.; Bala, S.; Kodys, K.; Szabo, G.G. Exosomes derived from alcohol-treated hepatocytes horizontally transfer liver specific miRNA-122 and sensitize monocytes to LPS. Sci. Rep. 2015, 5, 9991. [CrossRef]

59. Bala, S.; Petrasek, J.; Mundkur, S.; Catalano, D.; Levin, I.; Ward, J.; Alao, H.; Kodys, K.; Szabo, G.G. Circulating microRNAs in exosomes indicate hepatocyte injury and inflammation in alcoholic, drug-induced, and inflammatory liver diseases. Hepatology 2012, 56, 1946-1957. [CrossRef]

60. Ma, Z.; Liu, X.; Dong, H.; Xia, D.; Wang, L.; Chen, Y.; Xiong, Y.Y. Sorafenib and praziquantel synergistically attenuate Schistosoma japonicum-induced liver fibrosis in mice. Parasitol. Res. 2018, 117, 2831-2839. [CrossRef]

61. Ying, H.Z.; Chen, Q.; Zhang, W.Y.; Zhang, H.H.; Ma, Y.; Zhang, S.Z.; Fang, J.; Yu, C.H.H. PDGF signaling pathway in hepatic fibrosis pathogenesis and therapeutics (Review). Mol. Med. Rep. 2017, 16, 7879-7889. [CrossRef] [PubMed]

62. Wei, J.; Feng, L.; Li, Z.; Xu, G.; Fan, X.X. MicroRNA-21 activates hepatic stellate cells via PTEN/Akt signaling. Biomed. Pharm. 2013, 67, 387-392. [CrossRef]

63. Marquez, R.T.; Bandyopadhyay, S.; Wendlandt, E.B.; Keck, K.; Hoffer, B.A.; Icardi, M.S.; Christensen, R.N.; Schmidt, W.N.; McCaffrey, A.P.P. Correlation between microRNA expression levels and clinical parameters associated with chronic hepatitis $C$ viral infection in humans. Lab. Invest. 2010, 90, 1727-1736. [CrossRef]

64. Chen, B.L.; Peng, J.; Li, Q.F.; Yang, M.; Wang, Y.; Chen, W.W. Exogenous bone morphogenetic protein-7 reduces hepatic fibrosis in Schistosoma japonicum-infected mice via transforming growth factor-beta/Smad signaling. World J. Gastroenterol. 2013, 19, 1405-1415. [CrossRef]

65. Luo, X.; Zhang, D.; Xie, J.; Su, Q.; He, X.; Bai, R.; Gao, G.; Pan, W.W. MicroRNA-96 Promotes Schistosomiasis hepatic fibrosis in mice by suppressing Smad7. Mol. Methods Clin. Dev. 2018, 11, 73-82. [CrossRef]

66. Singh, A.K.; Rooge, S.B.; Varshney, A.; Vasudevan, M.; Bhardwaj, A.; Venugopal, S.K.; Trehanpati, N.; Kumar, M.; Geffers, R.; Kumar, V.; et al. Global microRNA expression profiling in the liver biopsies of hepatitis B virus-infected patients suggests specific microRNA signatures for viral persistence and hepatocellular injury. Hepatology 2018, 67, 1695-1709. [CrossRef] [PubMed]

67. Markovic, J.; Sharma, A.D.; Balakrishnan, A.A. MicroRNA-221: A fine tuner and potential biomarker of chronic liver injury. Cells 2020, 9, 1767. [CrossRef]

68. Shaker, O.G.; Senousy, M.A.A. Serum microRNAs as predictors for liver fibrosis staging in hepatitis C virus-associated chronic liver disease patients. J. Viral. Hepat. 2017, 24, 636-644. [CrossRef]

69. Park, J.K.; Kogure, T.; Nuovo, G.J.; Jiang, J.; He, L.; Kim, J.H.; Phelps, M.A.; Papenfuss, T.L.; Croce, C.M.; Patel, T.; et al. miR-221 silencing blocks hepatocellular carcinoma and promotes survival. Cancer Res. 2011, 71, 7608-7616. [CrossRef] 
70. Jiang, X.; Jiang, L.; Shan, A.; Su, Y.; Cheng, Y.; Song, D.; Ji, H.; Ning, G.; Wang, W.; Cao, Y.Y. Targeting hepatic miR-221/222 for therapeutic intervention of nonalcoholic steatohepatitis in mice. EBioMedicine 2018, 37, 307-321. [CrossRef] [PubMed]

71. Menghini, R.; Federici, M.M. MicroRNA 221/222 cluster kicks out Timp-3 to inflame the liver. EBioMedicine 2018, 37, 7-8. [CrossRef] [PubMed]

72. Bataller, R.; Brenner, D.A.A. Liver fibrosis. J. Clin. Invest. 2005, 115, 209-218. [CrossRef]

73. Huang, Y.H.; Yang, Y.L.; Huang, F.C.; Tiao, M.M.; Lin, Y.C.; Tsai, M.H.; Wang, F.S.S. MicroRNA-29a mitigation of endoplasmic reticulum and autophagy aberrance counteracts in obstructive jaundice-induced fibrosis in mice. Exp. Biol. Med. (Maywood) 2018, 243, 13-21. [CrossRef]

74. Huang, Y.H.; Yang, Y.L.; Wang, F.S.S. The Role of miR-29a in the Regulation, Function, and Signaling of Liver Fibrosis. Int. J. Mol. Sci. 2018, 19, 1889. [CrossRef]

75. Wang, S.; Qiu, L.; Yan, X.; Jin, W.; Wang, Y.; Chen, L.; Wu, E.; Ye, X.; Gao, G.F.; Wang, F.; et al. Loss of microRNA 122 expression in patients with hepatitis B enhances hepatitis B virus replication through cyclin G(1) -modulated P53 activity. Hepatology 2012, 55, 730-741. [CrossRef] [PubMed]

76. Lin, Y.; Deng, W.; Pang, J.; Kemper, T.; Hu, J.; Yin, J.; Zhang, J.; Lu, M.M. The microRNA-99 family modulates hepatitis B virus replication by promoting IGF-1R/PI3K/Akt/mTOR/ULK1 signaling-induced autophagy. Cell. Microbiol. 2017, 19, e12709. [CrossRef]

77. Zhang, G.L.; Li, Y.X.; Zheng, S.Q.; Liu, M.; Li, X.; Tang, H.H. Suppression of hepatitis B virus replication by microRNA-199a-3p and microRNA-210. Antivir. Res. 2010, 88, 169-175. [CrossRef]

78. Hayes, C.N.; Chayama, K.K. MicroRNAs as Biomarkers for Liver Disease and Hepatocellular Carcinoma. Int. J. Mol. Sci. 2016, 17, 280. [CrossRef]

79. Banaudha, K.; Kaliszewski, M.; Korolnek, T.; Florea, L.; Yeung, M.L.; Jeang, K.T.; Kumar, A.A. MicroRNA silencing of tumor suppressor DLC-1 promotes efficient hepatitis C virus replication in primary human hepatocytes. Hepatology 2011, 53, 53-61. [CrossRef]

80. Matsuura, K.; De Giorgi, V.; Schechterly, C.; Wang, R.Y.; Farci, P.; Tanaka, Y.; Alter, H.J.J. Circulating let-7 levels in plasma and extracellular vesicles correlate with hepatic fibrosis progression in chronic hepatitis $\mathrm{C}$. Hepatology 2016, 64, 732-745. [CrossRef]

81. Abdel-Al, A.; El-Ahwany, E.; Zoheiry, M.; Hassan, M.; Ouf, A.; Abu-Taleb, H.; Abdel Rahim, A.; El-Talkawy, M.D.; Zada, S.S. miRNA-221 and miRNA-222 are promising biomarkers for progression of liver fibrosis in HCV Egyptian patients. Virus Res. 2018, 253, 135-139. [CrossRef]

82. McDaniel, K.; Huang, L.; Sato, K.; Wu, N.; Annable, T.; Zhou, T.; Ramos-Lorenzo, S.; Wan, Y.; Huang, Q.; Francis, H.; et al. The let-7/Lin28 axis regulates activation of hepatic stellate cells in alcoholic liver injury. J. Biol. Chem. 2017, 292, 11336-11347. [CrossRef] [PubMed]

83. Brandon-Warner, E.; Feilen, N.A.; Culberson, C.R.; Field, C.O.; deLemos, A.S.; Russo, M.W.; Schrum, L.W.W. Processing of miR179-2 Cluster in Hepatic Stellate Cells Promotes Hepatic Fibrogenesis During Alcohol-Induced Injury. Alcohol. Clin. Exp. Res. 2016, 40, 1430-1442. [CrossRef] [PubMed]

84. Torres, J.L.; Novo-Veleiro, I.; Manzanedo, L.; Alvela-Suarez, L.; Macias, R.; Laso, F.J.; Marcos, M.M. Role of microRNAs in alcohol-induced liver disorders and non-alcoholic fatty liver disease. World J. Gastroenterol. 2018, 24, 4104-4118. [CrossRef]

85. Csak, T.; Bala, S.; Lippai, D.; Kodys, K.; Catalano, D.; Iracheta-Vellve, A.; Szabo, G.G. MicroRNA-155 deficiency attenuates liver steatosis and fibrosis without reducing inflammation in a mouse model of steatohepatitis. PLoS ONE 2015, 10, e0129251. [CrossRef]

86. Wang, B.; Majumder, S.; Nuovo, G.; Kutay, H.; Volinia, S.; Patel, T.; Schmittgen, T.D.; Croce, C.; Ghoshal, K.; Jacob, S.T.T. Role of microRNA-155 at early stages of hepatocarcinogenesis induced by choline-deficient and amino acid-defined diet in C57BL/6 mice. Hepatology 2009, 50, 1152-1161. [CrossRef]

87. Mak, D.; Babb de Villiers, C.; Chasela, C.; Urban, M.I.; Kramvis, A.A. Analysis of risk factors associated with hepatocellular carcinoma in black South Africans: 20002-012. PLoS ONE 2018, 13, e0196057. [CrossRef]

88. Garzon, R.; Marcucci, G.; Croce, C.M.M. Targeting microRNAs in cancer: Rationale, strategies and challenges. Nat. Rev. Drug Discov. 2010, 9, 775-789. [CrossRef]

89. Chen, Y.; Shen, A.; Rider, P.J.; Yu, Y.; Wu, K.; Mu, Y.; Hao, Q.; Liu, Y.; Gong, H.; Zhu, Y.; et al. A liver-specific microRNA binds to a highly conserved RNA sequence of hepatitis $B$ virus and negatively regulates viral gene expression and replication. FASEB J. 2011, 25, 4511-4521. [CrossRef] 
90. Xu, J.; Zhu, X.; Wu, L.; Yang, R.; Yang, Z.; Wang, Q.; Wu, F.F. MicroRNA-122 suppresses cell proliferation and induces cell apoptosis in hepatocellular carcinoma by directly targeting Wnt/beta-catenin pathway. Liver Int. 2012, 32, 752-760. [CrossRef]

91. Gao, D.; Zhai, A.; Qian, J.; Li, A.; Li, Y.; Song, W.; Zhao, H.; Yu, X.; Wu, J.; Zhang, Q.; et al. Down-regulation of suppressor of cytokine signaling 3 by miR-122 enhances interferon-mediated suppression of hepatitis $\mathrm{B}$ virus. Antivir. Res. 2015, 118, 2-8. [CrossRef]

92. Xiao, C.; Rajewsky, K.K. MicroRNA control in the immune system: Basic principles. Cell 2009, 136, $26-36$. [CrossRef]

93. Wang, W.; Bian, H.; Li, F.; Li, X.; Zhang, D.; Sun, S.; Song, S.; Zhu, Q.; Ren, W.; Qin, C.; et al. HBeAg induces the expression of macrophage miR-155 to accelerate liver injury via promoting production of inflammatory cytokines. Cell. Mol. Life Sci. 2018, 75, 2627-2641. [CrossRef]

94. Niepmann, M.; Shalamova, L.A.; Gerresheim, G.K.; Rossbach, O.O. Signals involved in regulation of hepatitis C virus RNA genome translation and replication. Front. Microbiol. 2018, 9, 395. [CrossRef]

95. Niepmann, M.; Gerresheim, G.K.K. Hepatitis C virus translation regulation. Int. J. Mol. Sci. 2020, $21,2328$. [CrossRef]

96. Ura, S.; Honda, M.; Yamashita, T.; Ueda, T.; Takatori, H.; Nishino, R.; Sunakozaka, H.; Sakai, Y.; Horimoto, K.; Kaneko, S.S. Differential microRNA expression between hepatitis B and hepatitis Cleading disease progression to hepatocellular carcinoma. Hepatology 2009, 49, 1098-1112. [CrossRef]

97. Peng, X.; Li, Y.; Walters, K.A.; Rosenzweig, E.R.; Lederer, S.L.; Aicher, L.D.; Proll, S.; Katze, M.G.G. Computational identification of hepatitis $\mathrm{C}$ virus associated microRNA-mRNA regulatory modules in human livers. BMC Genom. 2009, 10, 373. [CrossRef] [PubMed]

98. Coll, M.; El Taghdouini, A.; Perea, L.; Mannaerts, I.; Vila-Casadesus, M.; Blaya, D.; Rodrigo-Torres, D.; Affo, S.; Morales-Ibanez, O.; Graupera, I.; et al. Integrative miRNA and gene expression profiling analysis of human quiescent hepatic stellate cells. Sci. Rep. 2015, 5, 11549. [CrossRef]

99. Mandrekar, P.; Szabo, G.G. Signalling pathways in alcohol-induced liver inflammation. J. Hepatol. 2009, 50, 1258-1266. [CrossRef] [PubMed]

100. Blaya, D.; Coll, M.; Rodrigo-Torres, D.; Vila-Casadesus, M.; Altamirano, J.; Llopis, M.; Graupera, I.; Perea, L.; Aguilar-Bravo, B.; Diaz, A.; et al. Integrative microRNA profiling in alcoholic hepatitis reveals a role for microRNA-182 in liver injury and inflammation. Gut 2016, 65, 1535-1545. [CrossRef]

101. Leti, F.; Malenica, I.; Doshi, M.; Courtright, A.; Van Keuren-Jensen, K.; Legendre, C.; Still, C.D.; Gerhard, G.S.; DiStefano, J.K.K. High-throughput sequencing reveals altered expression of hepatic microRNAs in nonalcoholic fatty liver disease-related fibrosis. Transl. Res. 2015, 166, 304-314. [CrossRef]

102. Guo, Y.; Xiong, Y.; Sheng, Q.; Zhao, S.; Wattacheril, J.; Flynn, C.R.R. A micro-RNA expression signature for human NAFLD progression. J. Gastroenterol. 2016, 51, 1022-1030. [CrossRef]

103. Chen, Y.; Siegel, F.; Kipschull, S.; Haas, B.; Frohlich, H.; Meister, G.; Pfeifer, A.A. miR-155 regulates differentiation of brown and beige adipocytes via a bistable circuit. Nat. Commun. 2013, 4, 1769. [CrossRef]

104. Khan, S.; Ayub, H.; Khan, T.; Wahid, F.F. MicroRNA biogenesis, gene silencing mechanisms and role in breast, ovarian and prostate cancer. Biochimie 2019, 167, 12-24. [CrossRef]

105. Borel, F.; Konstantinova, P.; Jansen, P.L.L. Diagnostic and therapeutic potential of miRNA signatures in patients with hepatocellular carcinoma. J. Hepatol. 2012, 56, 1371-1383. [CrossRef]

106. Morishita, A.; Iwama, H.; Fujihara, S.; Sakamoto, T.; Fujita, K.; Tani, J.; Miyoshi, H.; Yoneyama, H.; Himoto, T.; Masaki, T.T. MicroRNA profiles in various hepatocellular carcinoma cell lines. Oncol. Lett. 2016, 12, 1687-1692. [CrossRef]

107. Morishita, A.; Masaki, T.T. MicroRNAs as possible biomarkers for hepatocellular carcinoma. Hepatol. Res. 2018, 48, 499-501. [CrossRef] [PubMed]

108. Oura, K.; Fujita, K.; Morishita, A.; Iwama, H.; Nakahara, M.; Tadokoro, T.; Sakamoto, T.; Nomura, T.; Yoneyama, H.; Mimura, S.; et al. Serum microRNA-125a-5p as a potential biomarker of HCV-associated hepatocellular carcinoma. Oncol. Lett. 2019, 18, 8828-8890. [CrossRef]

109. Zhu, Q.; Gong, L.; Wang, J.; Tu, Q.; Yao, L.; Zhang, J.R.; Han, X.J.; Zhu, S.J.; Wang, S.M.; Li, Y.H.; et al. miR-10b exerts oncogenic activity in human hepatocellular carcinoma cells by targeting expression of CUB and sushi multiple domains 1 (CSMD1). BMC Cancer 2016, 16, 806. [CrossRef]

110. Wang, J.; Chu, Y.; Xu, M.; Zhang, X.; Zhou, Y.; Xu, M.M. miR-21 promotes cell migration and invasion of hepatocellular carcinoma by targeting KLF5. Oncol. Lett. 2019, 17, 2221-2227. [CrossRef] 
111. Koenig, A.B.; Barajas, J.M.; Guerrero, M.J.; Ghoshal, K.K. A Comprehensive Analysis of Argonaute-CLIP Data Identifies Novel, Conserved and Species-Specific Targets of miR-21 in Human Liver and Hepatocellular Carcinoma. Int. J. Mol. Sci. 2018, 19, 851. [CrossRef] [PubMed]

112. Feng, X.; Jiang, J.; Shi, S.; Xie, H.; Zhou, L.; Zheng, S.S. Knockdown of miR-25 increases the sensitivity of liver cancer stem cells to TRAIL-induced apoptosis via PTEN/PI3K/Akt/Bad signaling pathway. Int. J. Oncol. 2016, 49, 2600-2610. [CrossRef]

113. Yang, W.; Dou, C.; Wang, Y.; Jia, Y.; Li, C.; Zheng, X.; Tu, K.K. MicroRNA-92a contributes to tumor growth of human hepatocellular carcinoma by targeting FBXW7. Oncol. Rep. 2015, 34, 2576-2584. [CrossRef]

114. Iwai, N.; Yasui, K.; Tomie, A.; Gen, Y.; Terasaki, K.; Kitaichi, T.; Soda, T.; Yamada, N.; Dohi, O.; Seko, Y.; et al. Oncogenic miR-965-p inhibits apoptosis by targeting the caspase-9 gene in hepatocellular carcinoma. Int. J. Oncol. 2018, 53, 237-245.

115. Wang, Y.; Chen, F.; Zhao, M.; Yang, Z.; Zhang, S.; Ye, L.; Gao, H.; Zhang, X.X. MiR-107 suppresses proliferation of hepatoma cells through targeting HMGA2 mRNA 3'UTR. Biochem. Biophys. Res. Commun. 2016, 480, 455-460. [CrossRef]

116. Su, S.G.; Yang, M.; Zhang, M.F.; Peng, Q.Z.; Li, M.Y.; Liu, L.P.; Bao, S.Y.Y. miR-107-mediated decrease of HMGCS2 indicates poor outcomes and promotes cell migration in hepatocellular carcinoma. Int. J. Biochem. Cell Biol. 2017, 91, 53-59. [CrossRef]

117. Zeng, Y.B.; Liang, X.H.; Zhang, G.X.; Jiang, N.; Zhang, T.; Huang, J.Y.; Zhang, L.; Zeng, X.C.C. miRNA-135a promotes hepatocellular carcinoma cell migration and invasion by targeting forkhead box O1. Cancer Cell Int. 2016, 16, 63. [CrossRef]

118. Fu, X.; Wen, H.; Jing, L.; Yang, Y.; Wang, W.; Liang, X.; Nan, K.; Yao, Y.; Tian, T.T. MicroRNA-1555-p promotes hepatocellular carcinoma progression by suppressing PTEN through the PI3K/Akt pathway. Cancer Sci. 2017, 108, 620-631. [CrossRef]

119. Yang, J.; He, Y.; Zhai, N.; Ding, S.; Li, J.; Peng, Z.Z. MicroRNA-181a inhibits autophagy by targeting Atg5 in hepatocellular carcinoma. Front. Biosci. (Landmark Ed.) 2018, 23, 388-396.

120. Li, N.; Men, W.; Zheng, Y.; Wang, H.; Meng, X.X. Oroxin B induces apoptosis by down-regulating MicroRNA-221 resulting in the inactivation of the PTEN/PI3K/AKT pathway in liver cancer. Molecules 2019, 24, 4384. [CrossRef]

121. Huo, W.; Du, M.; Pan, X.; Zhu, X.; Gao, Y.; Li, Z.Z. miR-203a-3p.1 targets IL-24 to modulate hepatocellular carcinoma cell growth and metastasis. FEBS Open Bio. 2017, 7, 1085-1091. [CrossRef]

122. Yang, Y.; Zhang, J.; Xia, T.; Li, G.; Tian, T.; Wang, M.; Wang, R.; Zhao, L.; Yang, Y.; Lan, K.; et al. MicroRNA-210 promotes cancer angiogenesis by targeting fibroblast grow th factor receptor-like 1 in hepatocellular carcinoma. Oncol. Rep. 2016, 36, 2553-2562. [CrossRef]

123. Li, H.; Wang, H.; Ren, Z.Z. MicroRNA-2145-p Inhibits the invasion and migration of hepatocellular carcinoma cells by targeting wiskott-aldrich syndrome like. Cell. Physiol. Biochem. 2018, 46, 757-764. [CrossRef]

124. Chen, Y.L.; Xu, Q.P.; Guo, F.; Guan, W.H.H. MicroRNA-302d downregulates TGFBR2 expression and promotes hepatocellular carcinoma growth and invasion. Exp. Ther. Med. 2017, 13, 681-687. [CrossRef]

125. Yu, Q.; Yang, X.; Duan, W.; Li, C.; Luo, Y.; Lu, S.S. miRNA-346 promotes proliferation, migration and invasion in liver cancer. Oncol. Lett. 2017, 14, 3255-3260. [CrossRef]

126. Chang, R.M.; Xiao, S.; Lei, X.; Yang, H.; Fang, F.; Yang, L.Y.Y. miRNA-487a promotes proliferation and metastasis in hepatocellular carcinoma. Clin. Cancer Res. 2017, 23, 2593-2604. [CrossRef]

127. Xie, B.H.; He, X.; Hua, R.X.; Zhang, B.; Tan, G.S.; Xiong, S.Q.; Liu, L.S.; Chen, W.; Yang, J.Y.; Wang, X.N.; et al. Mir-765 promotes cell proliferation by downregulating INPP4B expression in human hepatocellular carcinoma. Cancer Biomark. 2016, 16, 405-413. [CrossRef]

128. Han, G.; Zhang, L.; Ni, X.; Chen, Z.; Pan, X.; Zhu, Q.; Li, S.; Wu, J.; Huang, X.; Wang, X.X. MicroRNA-873 promotes cell proliferation, migration, and invasion by directly targeting TSLC1 in hepatocellular carcinoma. Cell. Physiol. Biochem. 2018, 46, 2261-2270. [CrossRef]

129. Jia, B.; Tan, L.; Jin, Z.; Jiao, Y.; Fu, Y.; Liu, Y.Y. MiR-892a promotes hepatocellular carcinoma cells proliferation and invasion through targeting CD226. J. Cell. Biochem. 2017, 118, 1489-1496. [CrossRef]

130. Ye, Y.; Wei, Y.; Xu, Y.; Li, Y.; Wang, R.; Chen, J.; Zhou, Y.; Fu, Z.; Chen, Y.; Wang, X.; et al. Induced MiR-1249 expression by aberrant activation of Hedegehog signaling pathway in hepatocellular carcinoma. Exp. Cell Res. 2017, 355, 9-17. [CrossRef] 
131. Liu, Z.; Wang, Y.; Dou, C.; Sun, L.; Li, Q.; Wang, L.; Xu, Q.; Yang, W.; Liu, Q.; Tu, K.K. MicroRNA-1468 promotes tumor progression by activating PPAR-gamma-mediated AKT signaling in human hepatocellular carcinoma. J. Exp. Clin. Cancer Res. 2018, 37, 49. [CrossRef]

132. Cheng, L.; Wang, H.; Han, S.S. MiR-3910 promotes the growth and migration of cancer cells in the progression of hepatocellular carcinoma. Dig. Dis. Sci. 2017, 62, 2812-2820. [CrossRef] [PubMed]

133. Song, L.; Zhang, W.; Chang, Z.; Pan, Y.; Zong, H.; Fan, Q.; Wang, L.L. miR-4417 targets tripartite motif-containing 35 (TRIM35) and regulates pyruvate kinase muscle 2 (PKM2) phosphorylation to promote proliferation and suppress apoptosis in hepatocellular carcinoma cells. Med. Sci. Monit. 2017, 23, 1741-1750. [CrossRef] [PubMed]

134. Jin, F.; Wang, Y.; Li, M.; Zhu, Y.; Liang, H.; Wang, C.; Wang, F.; Zhang, C.Y.; Zen, K.; Li, L.L. MiR-26 enhances chemosensitivity and promotes apoptosis of hepatocellular carcinoma cells through inhibiting autophagy. Cell Death Dis. 2017, 8, e2540. [CrossRef] [PubMed]

135. Mahati, S.; Xiao, L.; Yang, Y.; Mao, R.; Bao, Y.Y. miR-29a suppresses growth and migration of hepatocellular carcinoma by regulating CLDN1. Biochem. Biophys. Res. Commun. 2017, 486, 732-737. [CrossRef]

136. Zhao, G.; Han, C.; Zhang, Z.; Wang, L.; Xu, J.J. Increased expression of microRNA-315-p inhibits cell proliferation, migration, and invasion via regulating $\mathrm{Sp} 1$ transcription factor in HepG2 hepatocellular carcinoma cell line. Biochem. Biophys. Res. Commun. 2017, 490, 371-377. [CrossRef]

137. Tian, Q.; Xiao, Y.; Wu, Y.; Liu, Y.; Song, Z.; Gao, W.; Zhang, J.; Yang, J.; Zhang, Y.; Guo, T.; et al. MicroRNA-33b suppresses the proliferation and metastasis of hepatocellular carcinoma cells through the inhibition of Sal-like protein 4 expression. Int. J. Mol. Med. 2016, 38, 1587-1595. [CrossRef]

138. Zhang, J.J.; Chen, J.T.; Hua, L.; Yao, K.H.; Wang, C.Y.Y. miR-98 inhibits hepatocellular carcinoma cell proliferation via targeting EZH2 and suppressing Wnt/beta-catenin signaling pathway. Biomed. Pharm. 2017, 85, 472-478. [CrossRef]

139. Jin, Y.; Wang, J.; Han, J.; Luo, D.; Sun, Z.Z. MiR-122 inhibits epithelial-mesenchymal transition in hepatocellular carcinoma by targeting Snail1 and Snail2 and suppressing WNT/beta-cadherin signaling pathway. Exp. Cell Res. 2017, 360, 210-217. [CrossRef]

140. Li, G.; Zhang, W.; Gong, L.; Huang, X.X. MicroRNA 125a-5p inhibits cell proliferation and induces apoptosis in hepatitis b virus-related hepatocellular carcinoma by downregulation of ErbB3. Oncol. Res. 2019, 27, 449-458. [CrossRef]

141. Kim, J.K.; Noh, J.H.; Jung, K.H.; Eun, J.W.; Bae, H.J.; Kim, M.G.; Chang, Y.G.; Shen, Q.; Park, W.S.; Lee, J.Y.; et al. Sirtuin7 oncogenic potential in human hepatocellular carcinoma and its regulation by the tumor suppressors MiR-125a-5p and MiR-125b. Hepatology 2013, 57, 1055-1067. [CrossRef]

142. Jing, B.Q.; Ou, Y.; Zhao, L.; Xie, Q.; Zhang, Y.X.X. Experimental study on the prevention of liver cancer angiogenesis via miR-126. Eur. Rev. Med. Pharm. Sci. 2017, 21, 5096-5100.

143. Cui, S.; Sun, Y.; Liu, Y.; Liu, C.; Wang, J.; Hao, G.; Sun, Q.Q. MicroRNA137 has a suppressive role in liver cancer via targeting EZH2. Mol. Med. Rep. 2017, 16, 9494-9502. [CrossRef]

144. Yu, Q.; Xiang, L.; Yin, L.; Liu, X.; Yang, D.; Zhou, J.J. Loss-of-function of miR-142 by hypermethylation promotes TGF-beta-mediated tumour growth and metastasis in hepatocellular carcinoma. Cell Prolif. 2017, 50, e12384. [CrossRef]

145. Su, F.; Zhao, J.; Qin, S.; Wang, R.; Li, Y.; Wang, Q.; Tan, Y.; Jin, H.; Zhu, F.; Ou, Y.; et al. Over-expression of Thrombospondin 4 correlates with loss of miR-142 and contributes to migration and vascular invasion of advanced hepatocellular carcinoma. Oncotarget 2017, 8, 23277-23288. [CrossRef] [PubMed]

146. Hua, S.; Liu, C.; Liu, L.; Wu, D.D. miR-1423-p inhibits aerobic glycolysis and cell proliferation in hepatocellular carcinoma via targeting LDHA. Biochem. Biophys. Res. Commun. 2018, 496, 947-954. [CrossRef]

147. Bao, H.; Li, X.; Li, H.; Xing, H.; Xu, B.; Zhang, X.; Liu, Z.Z. MicroRNA-144 inhibits hepatocellular carcinoma cell proliferation, invasion and migration by targeting ZFX. J. Biosci. 2017, 42, 103-111. [CrossRef]

148. Dou, C.; Liu, Z.; Xu, M.; Jia, Y.; Wang, Y.; Li, Q.; Yang, W.; Zheng, X.; Tu, K.; Liu, Q.Q. miR-1873-p inhibits the metastasis and epithelial-mesenchymal transition of hepatocellular carcinoma by targeting S100A4. Cancer Lett. 2016, 381, 380-390. [CrossRef]

149. Zhao, Y.; Li, F.; Zhang, X.; Liu, A.; Qi, J.; Cui, H.; Zhao, P.P. MicroRNA-194 acts as a prognostic marker and inhibits proliferation in hepatocellular carcinoma by targeting MAP4K4. Int. J. Clin. Exp. Pathol. 2015, 8, 12446-12454. [PubMed] 
150. Ding, J.; Huang, S.; Wang, Y.; Tian, Q.; Zha, R.; Shi, H.; Wang, Q.; Ge, C.; Chen, T.; Zhao, Y.; et al. Genome-wide screening reveals that miR-195 targets the TNF-alpha/NF-kappaB pathway by down-regulating IkappaB kinase alpha and TAB3 in hepatocellular carcinoma. Hepatology 2013, 58, 654-666. [CrossRef] [PubMed]

151. Wang, R.; Zhao, N.; Li, S.; Fang, J.H.; Chen, M.X.; Yang, J.; Jia, W.H.; Yuan, Y.; Zhuang, S.M.M. MicroRNA-195 suppresses angiogenesis and metastasis of hepatocellular carcinoma by inhibiting the expression of VEGF, VAV2, and CDC42. Hepatology 2013, 58, 642-653. [CrossRef]

152. Ghosh, A.; Dasgupta, D.; Ghosh, A.; Roychoudhury, S.; Kumar, D.; Gorain, M.; Butti, R.; Datta, S.; Agarwal, S.; Gupta, S.; et al. MiRNA199a-3p suppresses tumor growth, migration, invasion and angiogenesis in hepatocellular carcinoma by targeting VEGFA, VEGFR1, VEGFR2, HGF and MMP2. Cell Death Dis. 2017, 8, e2706. [CrossRef]

153. Ren, K.; Li, T.; Zhang, W.; Ren, J.; Li, Z.; Wu, G.G. miR-199a-3p inhibits cell proliferation and induces apoptosis by targeting YAP1, suppressing Jagged1-Notch signaling in human hepatocellular carcinoma. J. Biomed. Sci. 2016, 23, 79. [CrossRef]

154. Zhou, S.J.; Liu, F.Y.; Zhang, A.H.; Liang, H.F.; Wang, Y.; Ma, R.; Jiang, Y.H.; Sun, N.F.F. MicroRNA-199b-5p attenuates TGF-beta1-induced epithelial-mesenchymal transition in hepatocellular carcinoma. Br. J. Cancer 2017, 117, 233-244. [CrossRef] [PubMed]

155. Wang, J.; Song, W.; Shen, W.; Yang, X.; Sun, W.; Qu, S.; Shang, R.; Ma, B.; Pu, M.; Tao, K.; et al. MicroRNA-200a suppresses cell invasion and migration by directly targeting GAB1 in hepatocellular carcinoma. Oncol. Res. 2017, 25, 1-10. [CrossRef]

156. Zheng, X.B.; Chen, X.B.; Xu, L.L.; Zhang, M.; Feng, L.; Yi, P.S.; Tang, J.W.; Xu, M.Q.Q. miR-203 inhibits augmented proliferation and metastasis of hepatocellular carcinoma residual in the promoted regenerating liver. Cancer Sci. 2017, 108, 338-346. [CrossRef]

157. Wu, H.; Tao, J.; Li, X.; Zhang, T.; Zhao, L.; Wang, Y.; Zhang, L.; Xiong, J.; Zeng, Z.; Zhan, N.; et al. MicroRNA-206 prevents the pathogenesis of hepatocellular carcinoma by modulating expression of met proto-oncogene and cyclin-dependent kinase 6 in mice. Hepatology 2017, 66, 1952-1967. [CrossRef]

158. Jia, P.; Wei, G.; Zhou, C.; Gao, Q.; Wu, Y.; Sun, X.; Li, X.X. Upregulation of MiR-212 inhibits migration and tumorigenicity and inactivates wnt/beta-catenin signaling in human hepatocellular carcinoma. Technol. Cancer Res. Treat. 2018, 17, 1533034618765221. [CrossRef]

159. Wang, L.; Bo, X.; Zheng, Q.; Xiao, X.; Wu, L.; Li, B.B. miR-296 inhibits proliferation and induces apoptosis by targeting FGFR1 in human hepatocellular carcinoma. FEBS Lett. 2016, 590, 4252-4262. [CrossRef]

160. Wang, L.; Yao, J.; Shi, X.; Hu, L.; Li, Z.; Song, T.; Huang, C.C. MicroRNA-302b suppresses cell proliferation by targeting EGFR in human hepatocellular carcinoma SMMC-7721 cells. BMC Cancer 2013, 13, 448. [CrossRef]

161. Wang, L.; Yao, J.; Sun, H.; Sun, R.; Chang, S.; Yang, Y.; Song, T.; Huang, C.C. miR-302b suppresses cell invasion and metastasis by directly targeting AKT2 in human hepatocellular carcinoma cells. Tumour Biol. 2016, 37, 847-855. [CrossRef]

162. Cui, H.; Song, R.; Wu, J.; Wang, W.; Chen, X.; Yin, J.J. MicroRNA-337 regulates the PI3K/AKT and Wnt/beta-catenin signaling pathways to inhibit hepatocellular carcinoma progression by targeting high-mobility group AT-hook 2. Am. J. Cancer Res. 2018, 8, 405-421. [PubMed]

163. Zhang, T.; Liu, W.; Zeng, X.C.; Jiang, N.; Fu, B.S.; Guo, Y.; Yi, H.M.; Li, H.; Zhang, Q.; Chen, W.J.; et al. Down-regulation of microRNA-3383-p promoted angiogenesis in hepatocellular carcinoma. Biomed. Pharm. 2016, 84, 583-591. [CrossRef]

164. Yuan, J.; Ji, H.; Xiao, F.; Lin, Z.; Zhao, X.; Wang, Z.; Zhao, J.; Lu, J.J. MicroRNA-340 inhibits the proliferation and invasion of hepatocellular carcinoma cells by targeting JAK1. Biochem. Biophys. Res. Commun. 2017, 483, 578-584. [CrossRef]

165. Yu, M.; Xue, H.; Wang, Y.; Shen, Q.; Jiang, Q.; Zhang, X.; Li, K.; Jia, M.; Jia, J.; Xu, J.; et al. miR-345 inhibits tumor metastasis and EMT by targeting IRF1-mediated mTOR/STAT3/AKT pathway in hepatocellular carcinoma. Int. J. Oncol. 2017, 50, 975-983. [CrossRef]

166. Pan, X.P.; Wang, H.X.; Tong, D.M.; Li, Y.; Huang, L.H.; Wang, C.C. miRNA-370 acts as a tumor suppressor via the downregulation of PIM1 in hepatocellular carcinoma. Eur. Rev. Med. Pharm. Sci. 2017, 21, 1254-1263.

167. Liu, X.; Zhang, A.; Xiang, J.; Lv, Y.; Zhang, X.X. miR-451 acts as a suppressor of angiogenesis in hepatocellular carcinoma by targeting the IL-6R-STAT3 pathway. Oncol. Rep. 2016, 36, 1385-1392. [CrossRef]

168. Zhang, M.; Wu, J.; Zhang, R.; Yang, J.; Zhang, Q.; Liu, B.B. miR-497 inhibits the carcinogenesis of hepatocellular carcinoma by targeting the Rictor/Akt signal pathway. Int. J. Clin. Exp. Pathol. 2019, 12, 1992-2000. 
169. Ye, Y.; Zhuang, J.; Wang, G.; He, S.; Zhang, S.; Wang, G.; Ni, J.; Wang, J.; Xia, W.W. MicroRNA-495 suppresses cell proliferation and invasion of hepatocellular carcinoma by directly targeting insulin-like growth factor receptor-1. Exp.Ther. Med. 2018, 15, 1150-1158. [CrossRef]

170. Liu, Y.; Hong, W.; Zhou, C.; Jiang, Z.; Wang, G.; Wei, G.; Li, X.X. miR-539 inhibits FSCN1 expression and suppresses hepatocellular carcinoma migration and invasion. Oncol. Rep. 2017, 37, 2593-2602. [CrossRef] [PubMed]

171. Zhang, Y.; Zhang, D.; Jiang, J.; Dong, L.L. Loss of miR-638 promotes invasion and epithelial-mesenchymal transition by targeting SOX2 in hepatocellular carcinoma. Oncol. Rep. 2017, 37, 323-332. [CrossRef]

172. Cheng, J.; Chen, Y.; Zhao, P.; Liu, X.; Dong, J.; Li, J.; Huang, C.; Wu, R.; Lv, Y.Y. Downregulation of miRNA-638 promotes angiogenesis and growth of hepatocellular carcinoma by targeting VEGF. Oncotarget 2016, 7, 30702-30711. [CrossRef]

173. Huang, W.; Li, J.; Guo, X.; Zhao, Y.; Yuan, X.X. miR-663a inhibits hepatocellular carcinoma cell proliferation and invasion by targeting HMGA2. Biomed. Pharm. 2016, 81, 431-438. [CrossRef]

174. Zhang, Y.; Wei, Y.; Li, X.; Liang, X.; Wang, L.; Song, J.; Zhang, X.; Zhang, C.; Niu, J.; Zhang, P.; et al. microRNA-874 suppresses tumor proliferation and metastasis in hepatocellular carcinoma by targeting the DOR/EGFR/ERK pathway. Cell Death Dis. 2018, 9, 130. [CrossRef]

175. Ding, D.; Zhang, Y.; Yang, R.; Wang, X.; Ji, G.; Huo, L.; Shao, Z.; Li, X.X. miR-940 suppresses tumor cell invasion and migration via regulation of CXCR2 in hepatocellular carcinoma. Biomed. Res. Int. 2016, 2016, 7618342. [CrossRef]

176. Lin, M.F.; Yang, Y.F.; Peng, Z.P.; Zhang, M.F.; Liang, J.Y.; Chen, W.; Liu, X.H.; Zheng, Y.L.L. FOXK2, regulted by miR-12715-p, promotes cell growth and indicates unfavorable prognosis in hepatocellular carcinoma. Int. J. Biochem. Cell Biol. 2017, 88, 155-161. [CrossRef] [PubMed]

177. Zhu, H.; Wang, G.; Zhou, X.; Song, X.; Gao, H.; Ma, C.; Chang, H.; Li, H.; Liu, F.F.; Lu, J.; et al. miR-1299 suppresses cell proliferation of hepatocellular carcinoma (HCC) by targeting CDK6. Biomed. Pharm. 2016, 83, 792-797. [CrossRef]

178. Yang, C.; Xu, Y.; Cheng, F.; Hu, Y.; Yang, S.; Rao, J.; Wang, X.X. miR-1301 inhibits hepatocellular carcinoma cell migration, invasion, and angiogenesis by decreasing Wnt/beta-catenin signaling through targeting BCL9. Cell Death Dis. 2017, 8, e2999. [CrossRef]

179. Slack, F.J.; Chinnaiyan, A.M.M. The role of non-coding RNAs in oncology. Cell 2019, 179, $1033-1055$. [CrossRef]

180. Wang, X.W.; Heegaard, N.H.; Orum, H.H. MicroRNAs in liver disease. Gastroenterology 2012, 142, 1431-1443. [CrossRef]

181. Zhang, T.; Yang, Z.; Kusumanchi, P.; Han, S.; Liangpunsakul, S.S. Critical role of microRNA-21 in the pathogenesis of liver diseases. Front. Med. (Lausanne) 2020, 7, 7. [CrossRef]

182. Mishra, P.J.; Bertino, J.R.R. MicroRNA polymorphisms: The future of pharmacogenomics, molecular epidemiology and individualized medicine. Pharmacogenomics 2009, 10, 399-416. [CrossRef] [PubMed]

183. Guo, X.; Lv, X.; Lv, X.; Ma, Y.; Chen, L.; Chen, Y.Y. Circulating miR-21 serves as a serum biomarker for hepatocellular carcinoma and correlated with distant metastasis. Oncotarget 2017, 8, 44050-44058. [CrossRef]

184. Yoon, J.S.; Kim, G.; Lee, Y.R.; Park, S.Y.; Tak, W.Y.; Kweon, Y.O.; Park, J.G.; Lee, H.W.; Han, Y.S.; Ha, H.T.; et al. Clinical significance of microRNA-21 expression in disease progression of patients with hepatocellular carcinoma. Biomark. Med. 2018, 12, 1105-1114. [CrossRef]

185. Zhou, Y.; Ren, H.; Dai, B.; Li, J.; Shang, L.; Huang, J.; Shi, X.X. Hepatocellular carcinoma-derived exosomal miRNA-21 contributes to tumor progression by converting hepatocyte stellate cells to cancer-associated fibroblasts. J. Exp. Clin. Cancer Res. 2018, 37, 324. [CrossRef] [PubMed]

186. Chen, M.; Liu, Y.; Varley, P.; Chang, Y.; He, X.X.; Huang, H.; Tang, D.; Lotze, M.T.; Lin, J.; Tsung, A.A. High-mobility group box 1 promotes hepatocellular carcinoma progression through miR-21-mediated matrix metalloproteinase activity. Cancer Res. 2015, 75, 1645-1656. [CrossRef]

187. Blaya, D.; Aguilar-Bravo, B.; Hao, F.; Casacuberta-Serra, S.; Coll, M.; Perea, L.; Vallverdu, J.; Graupera, I.; Pose, E.; Llovet, L.; et al. Expression of microRNA-155 in inflammatory cells modulates liver injury. Hepatology 2018, 68, 691-706. [CrossRef]

188. Chen, Z.; Ma, T.; Huang, C.; Hu, T.; Li, J.J. The pivotal role of microRNA-155 in the control of cancer. J. Cell. Physiol. 2014, 229, 545-550. [CrossRef] 
189. Yan, X.L.; Jia, Y.L.; Chen, L.; Zeng, Q.; Zhou, J.N.; Fu, C.J.; Chen, H.X.; Yuan, H.F.; Li, Z.W.; Shi, L.; et al. Hepatocellular carcinoma-associated mesenchymal stem cells promote hepatocarcinoma progression: Role of the S100A4-miR155-SOCS1-MMP9 axis. Hepatology 2013, 57, 2274-2286. [CrossRef]

190. Pineau, P.; Volinia, S.; McJunkin, K.; Marchio, A.; Battiston, C.; Terris, B.; Mazzaferro, V.; Lowe, S.W.; Croce, C.M.; Dejean, A.A. miR-221 overexpression contributes to liver tumorigenesis. Proc. Natl. Acad. Sci. USA 2010, 107, 264-269. [CrossRef]

191. Johnson, S.M.; Grosshans, H.; Shingara, J.; Byrom, M.; Jarvis, R.; Cheng, A.; Labourier, E.; Reinert, K.L.; Brown, D.; Slack, F.J.J. RAS is regulated by the let-7 microRNA family. Cell 2005, 120, 635-647. [CrossRef]

192. Winkler, I.; Bitter, C.; Winkler, S.; Weichenhan, D.; Thavamani, A.; Hengstler, J.G.; Borkham-Kamphorst, E.; Kohlbacher, O.; Plass, C.; Geffers, R.; et al. Identification of Ppargamma-modulated miRNA hubs that target the fibrotic tumor microenvironment. Proc. Natl. Acad. Sci. USA 2020, 117, 454-463. [CrossRef] [PubMed]

193. Ji, J.; Zhao, L.; Budhu, A.; Forgues, M.; Jia, H.L.; Qin, L.X.; Ye, Q.H.; Yu, J.; Shi, X.; Tang, Z.Y.; et al. Let-7g targets collagen type I alpha2 and inhibits cell migration in hepatocellular carcinoma. J. Hepatol. 2010, 52, 690-697. [CrossRef]

194. Kwon, J.J.; Factora, T.D.; Dey, S.; Kota, J.J. A systematic review of miR-29 in Cancer. Mol. Ther. Oncolytics 2019, 12, 173-194. [CrossRef]

195. Xiong, Y.; Fang, J.H.; Yun, J.P.; Yang, J.; Zhang, Y.; Jia, W.H.; Zhuang, S.M.M. Effects of microRNA-29 on apoptosis, tumorigenicity, and prognosis of hepatocellular carcinoma. Hepatology 2010, 51, 836-845. [CrossRef]

196. Su, H.; Yang, J.R.; Xu, T.; Huang, J.; Xu, L.; Yuan, Y.; Zhuang, S.M.M. MicroRNA-101, down-regulated in hepatocellular carcinoma, promotes apoptosis and suppresses tumorigenicity. Cancer Res. 2009, 69, 1135-1142. [CrossRef] [PubMed]

197. Weidle, U.H.; Schmid, D.; Birzele, F.; Brinkmann, U.U. MicroRNAs Involved in Metastasis of Hepatocellular Carcinoma: Target Candidates, Functionality and Efficacy in Animal Models and Prognostic Relevance. Cancer Genom. Proteom. 2020, 17, 1-21. [CrossRef]

198. Cheng, D.; Deng, J.; Zhang, B.; He, X.; Meng, Z.; Li, G.; Ye, H.; Zheng, S.; Wei, L.; Deng, X.; et al. LncRNA HOTAIR epigenetically suppresses miR-122 expression in hepatocellular carcinoma via DNA methylation. EBioMedicine 2018, 36, 159-170. [CrossRef]

199. Tomimaru, Y.; Eguchi, H.; Nagano, H.; Wada, H.; Kobayashi, S.; Marubashi, S.; Tanemura, M.; Tomokuni, A.; Takemasa, I.; Umeshita, K.; et al. Circulating microRNA-21 as a novel biomarker for hepatocellular carcinoma. J. Hepatol. 2012, 56, 167-175. [CrossRef]

200. Gibbings, D.J.; Ciaudo, C.; Erhardt, M.; Voinnet, O.O. Multivesicular bodies associate with components of miRNA effector complexes and modulate miRNA activity. Nat. Cell Biol. 2009, 11, 1143-1149. [CrossRef] [PubMed]

201. Mitchell, P.S.; Parkin, R.K.; Kroh, E.M.; Fritz, B.R.; Wyman, S.K.; Pogosova-Agadjanyan, E.L.; Peterson, A.; Noteboom, J.; O’Briant, K.C.; Allen, A.; et al. Circulating microRNAs as stable blood-based markers for cancer detection. Proc. Natl. Acad. Sci. USA 2008, 105, 10513-10518. [CrossRef]

202. Hung, C.H.; Hu, T.H.; Lu, S.N.; Kuo, F.Y.; Chen, C.H.; Wang, J.H.; Huang, C.M.; Lee, C.M.; Lin, C.Y.; Yen, Y.H.; et al. Circulating microRNAs as biomarkers for diagnosis of early hepatocellular carcinoma associated with hepatitis B virus. Int. J. Cancer 2016, 138, 714-720. [CrossRef]

203. Xie, Y.; Yao, Q.; Butt, A.M.; Guo, J.; Tian, Z.; Bao, X.; Li, H.; Meng, Q.; Lu, J.J. Expression profiling of serum microRNA-101 in HBV-associated chronic hepatitis, liver cirrhosis, and hepatocellular carcinoma. Cancer Biol. Ther. 2014, 15, 1248-1255. [CrossRef] [PubMed]

204. Giray, B.G.; Emekdas, G.; Tezcan, S.; Ulger, M.; Serin, M.S.; Sezgin, O.; Altintas, E.; Tiftik, E.N.N. Profiles of serum microRNAs; miR-125b-5p and miR2233-p serve as novel biomarkers for HBV-positive hepatocellular carcinoma. Mol. Biol. Rep. 2014, 41, 4513-4519. [CrossRef] [PubMed]

205. Zekri, A.N.; Youssef, A.S.; El-Desouky, E.D.; Ahmed, O.S.; Lotfy, M.M.; Nassar, A.A.; Bahnassey, A.A.A. Serum microRNA panels as potential biomarkers for early detection of hepatocellular carcinoma on top of HCV infection. Tumour Biol. 2016, 37, 12273-12286. [CrossRef]

206. Chen, F.; Li, X.F.; Fu, D.S.; Huang, J.G.; Yang, S.E.E. Clinical potential of miRNA-221 as a novel prognostic biomarker for hepatocellular carcinoma. Cancer Biomark. 2017, 18, 209-214. [CrossRef] [PubMed] 
207. Xie, R.T.; Cong, X.L.; Zhong, X.M.; Luo, P.; Yang, H.Q.; Lu, G.X.; Luo, P.; Chang, Z.Y.; Sun, R.; Wu, T.M.; et al. MicroRNA-33a downregulation is associated with tumorigenesis and poor prognosis in patients with hepatocellular carcinoma. Oncol. Lett. 2018, 15, 4571-4577. [CrossRef]

208. Fu, X.; Liu, M.; Qu, S.; Ma, J.; Zhang, Y.; Shi, T.; Wen, H.; Yang, Y.; Wang, S.; Wang, J.; et al. Exosomal microRNA-325-p induces multidrug resistance in hepatocellular carcinoma via the PI3K/Akt pathway. J. Exp. Clin. Cancer Res. 2018, 37, 52. [CrossRef]

209. Shi, M.; Jiang, Y.; Yang, L.; Yan, S.; Wang, Y.G.; Lu, X.J.J. Decreased levels of serum exosomal miR-638 predict poor prognosis in hepatocellular carcinoma. J. Cell. Biochem. 2018, 119, 4711-4716. [CrossRef]

210. Wang, Y.; Zhang, C.; Zhang, P.; Guo, G.; Jiang, T.; Zhao, X.; Jiang, J.; Huang, X.; Tong, H.; Tian, Y.Y. Serum exosomal microRNAs combined with alpha-fetoprotein as diagnostic markers of hepatocellular carcinoma. Cancer Med. 2018, 7, 1670-1679. [CrossRef]

211. Chung, H.J.; Choi, Y.E.; Kim, E.S.; Han, Y.H.; Park, M.J.; Bae, I.H.H. miR-29b attenuates tumorigenicity and stemness maintenance in human glioblastoma multiforme by directly targeting BCL2L2. Oncotarget 2015, 6, 18429-18444. [CrossRef]

212. Kong, Y.W.; Ferland-McCollough, D.; Jackson, T.J.; Bushell, M.M. microRNAs in cancer management. Lancet Oncol. 2012, 13, e249-e258. [CrossRef]

213. Amodeo, V.; Bazan, V.; Fanale, D.; Insalaco, L.; Caruso, S.; Cicero, G.; Bronte, G.; Rolfo, C.; Santini, D.; Russo, A.A. Effects of anti-miR-182 on TSP-1 expression in human colon cancer cells: There is a sense in antisense? Expert Opin. Ther. Targets 2013, 17, 1249-1261. [CrossRef]

214. Nedaeinia, R.; Sharifi, M.; Avan, A.; Kazemi, M.; Rafiee, L.; Ghayour-Mobarhan, M.; Salehi, R.R. Locked nucleic acid anti-miR-21 inhibits cell growth and invasive behaviors of a colorectal adenocarcinoma cell line: LNA-anti-miR as a novel approach. Cancer Gene Ther. 2016, 23, 246-253. [CrossRef] [PubMed]

215. Kota, J.; Chivukula, R.R.; O’Donnell, K.A.; Wentzel, E.A.; Montgomery, C.L.; Hwang, H.W.; Chang, T.C.; Vivekanandan, P.; Torbenson, M.; Clark, K.R.; et al. Therapeutic microRNA delivery suppresses tumorigenesis in a murine liver cancer model. Cell 2009, 137, 1005-1017. [CrossRef]

216. Hsu, S.H.; Yu, B.; Wang, X.; Lu, Y.; Schmidt, C.R.; Lee, R.J.; Lee, L.J.; Jacob, S.T.; Ghoshal, K.K. Cationic lipid nanoparticles for therapeutic delivery of siRNA and miRNA to murine liver tumor. Nanomedicine 2013, 9 , 1169-1180. [CrossRef]

217. Inchingolo, R.; Posa, A.; Mariappan, M.; Spiliopoulos, S.S. Locoregional treatments for hepatocellular carcinoma: Current evidence and future directions. World J. Gastroenterol. 2019, 25, 4614-4628. [CrossRef]

218. Gottesman, M.M.M. Mechanisms of cancer drug resistance. Annu. Rev. Med. 2002, 53, 615-627. [CrossRef] [PubMed]

219. Korita, P.V.; Wakai, T.; Shirai, Y.; Matsuda, Y.; Sakata, J.; Takamura, M.; Yano, M.; Sanpei, A.; Aoyagi, Y.; Hatakeyama, K.; et al. Multidrug resistance-associated protein 2 determines the efficacy of cisplatin in patients with hepatocellular carcinoma. Oncol. Rep. 2010, 23, 965-972.

220. Wang, X.Q.; Ongkeko, W.M.; Chen, L.; Yang, Z.F.; Lu, P.; Chen, K.K.; Lopez, J.P.; Poon, R.T.; Fan, S.T.T. Octamer 4 (Oct4) mediates chemotherapeutic drug resistance in liver cancer cells through a potential Oct4-AKT-ATP-binding cassette G2 pathway. Hepatology 2010, 52, 528-539. [CrossRef]

221. Meng, W.; Tai, Y.; Zhao, H.; Fu, B.; Zhang, T.; Liu, W.; Li, H.; Yang, Y.; Zhang, Q.; Feng, Y.; et al. Downregulation of miR-33a-5p in hepatocellular carcinoma: A possible mechanism for chemotherapy resistance. Med. Sci. Monit. 2017, 23, 1295-1304. [CrossRef] [PubMed]

222. Wei, L.; Wang, X.; Lv, L.; Liu, J.; Xing, H.; Song, Y.; Xie, M.; Lei, T.; Zhang, N.; Yang, M.M. The emerging role of microRNAs and long noncoding RNAs in drug resistance of hepatocellular carcinoma. Mol. Cancer 2019, 18, 147. [CrossRef] [PubMed]

223. Ou, Y.; Zhai, D.; Wu, N.; Li, X.X. Downregulation of miR-363 increases drug resistance in cisplatin-treated HepG2 by dysregulating Mcl-1. Gene 2015, 572, 116-122. [CrossRef]

224. Ma, J.; Wang, T.; Guo, R.; Yang, X.; Yin, J.; Yu, J.; Xiang, Q.; Pan, X.; Tang, H.; Lei, X.X. Involvement of miR-133a and miR-326 in ADM resistance of HepG2 through modulating expression of ABCC1. J. Drug Target. 2015, 23, 519-524. [CrossRef]

225. Shi, L.; Wu, L.; Chen, Z.; Yang, J.; Chen, X.; Yu, F.; Zheng, F.; Lin, X.X. MiR-141 activates Nrf2-dependent antioxidant pathway via down-regulating the expression of keap1 conferring the resistance of hepatocellular carcinoma cells to 5-fluorouracil. Cell. Physiol. Biochem. 2015, 35, 2333-2348. [CrossRef] 
226. Lee, H.; Kim, C.; Kang, H.; Tak, H.; Ahn, S.; Yoon, S.K.; Kuh, H.J.; Kim, W.; Lee, E.K.K. microRNA-200a-3p increases 5-fluorouracil resistance by regulating dual specificity phosphatase 6 expression. Exp. Mol. Med. 2017, 49, e327. [CrossRef]

227. Wang, X.J.; Zhang, D.L.; Fu, C.; Wei, B.Z.; Li, G.J.J. MiR-183 modulates multi-drug resistance in hepatocellular cancer (HCC) cells via miR-183-IDH2/SOCS6-HIF-1alpha feedback loop. Eur. Rev. Med. Pharm. Sci. 2016, 20, 2020-2027.

228. Yang, X.; Zang, J.; Pan, X.; Yin, J.; Xiang, Q.; Yu, J.; Gan, R.; Lei, X.X. miR-503 inhibits proliferation making human hepatocellular carcinoma cells susceptible to 5fluorouracil by targeting EIF4E. Oncol. Rep. 2017, 37, 563-570. [CrossRef] [PubMed]

229. Xia, H.; Ooi, L.L.; Hui, K.M.M. MicroRNA-216a/217-induced epithelial-mesenchymal transition targets PTEN and SMAD7 to promote drug resistance and recurrence of liver cancer. Hepatology 2013, 58, 629-641. [CrossRef]

230. Azumi, J.; Tsubota, T.; Sakabe, T.; Shiota, G.G. miR-181a induces sorafenib resistance of hepatocellular carcinoma cells through downregulation of RASSF1 expression. Cancer Sci. 2016, 107, 1256-1262. [CrossRef]

231. Liu, K.; Liu, S.; Zhang, W.; Jia, B.; Tan, L.; Jin, Z.; Liu, Y.Y. miR-494 promotes cell proliferation, migration and invasion, and increased sorafenib resistance in hepatocellular carcinoma by targeting PTEN. Oncol. Rep. 2015, 34, 1003-1010. [CrossRef]

Publisher's Note: MDPI stays neutral with regard to jurisdictional claims in published maps and institutional affiliations. 